UNIVERSIDADE DE SÃO PAULO

\title{
O SIGNIFICADO DA EXPERIÊNCIA DE ABRIGO E A AUTO-IMAGEM DA CRIANÇA EM IDADE ESCOLAR
}

DANIELA CRISTINA MONTES

SÃO PAULO

2006 
UNIVERSIDADE DE SÃO PAULO

\section{O SIGNIFICADO DA EXPERIÊNCIA DE ABRIGO E A AUTO-IMAGEM DA CRIANÇA EM IDADE ESCOLAR}

\section{DANIELA CRISTINA MONTES}

Dissertação apresentada à Escola de Enfermagem da Universidade de São Paulo para obtenção do título de Mestre Área de Concentração: Enfermagem Pediátrica

Orientadora: Prof ${ }^{a}$. Dr ${ }^{a}$. Moneda Oliveira Ribeiro

SÃO PAULO

2006 


\section{Catalogação na publicação (CIP) \\ Biblioteca "Wanda de Aguiar Horta" da EEUSP}

Montes, Daniela Cristina

O significado da experiência de abrigo e a auto-imagem da criança em idade escolar. / Daniela Cristina Montes. - São Paulo:

D.C. Montes; 2006.

$98 \mathrm{p}$.

Dissertação (Mestrado) - Escola de Enfermagem da Universidade de São Paulo.

Orientadora: $\operatorname{Prof}^{\mathrm{a}} \mathrm{Dr}^{\mathrm{a}}$ Moneda Oliveira Ribeiro

1. Crianças abrigadas 2. Auto-imagem 3. Exclusão social 4. Saúde escolar I. Título. 
Às crianças que participaram deste estudo. Obrigada por compartilharem suas histórias.

Aos meus avós, por terem repleto minha infância de beleza e fantasia.

Aos meus pais, pela oportunidade de viver no "Pais da Infância".

Aos meus irmãos, por compartilharem esse "País" comigo.

Ao meu marido, um "mestre" no cuidar. 
A Profa. Dra. Moneda Oliveira Ribeiro, pela orientação, competência, amizade e paciência.

Aos amigos, principalmente, Lucilene Cordeiro, Rita Conti, Rose Fracolli e Rose Shibayama, pela paciência, incentivo e confiança.

À Leonardo Wilde pela cooperação na transcrição das fitas.

À Diretora do abrigo e à sua equipe técnica. Obrigada pela oportunidade e confiança.

À Universidade Nove de Julho e ao SENAC, pelo apoio e compreensão nos momentos críticos. 


\section{RESUMO}

A experiência da criança em situação de abrigo pode dificultar 0 desenvolvimento de uma auto-imagem positiva quando o abrigo não atende os princípios estabelecidos por lei. Os valores, as crenças, as imagens, as atitudes e o conjunto de informações vividas na infância delineiam a imagem que a criança tem de si. Por isso, é necessário estudar em que medida o abrigo, em sua função de proteção, contribui, ou não, para a formação da auto-imagem da criança em situação de risco pessoal e social.

Se, por um lado, a situação de abrigo pode evitar ou reduzir danos à criança que, no seio da família, se encontrava em situação de risco; por outro, pode causar prejuízos na formação da auto-imagem da criança. Assim, esse estudo teve o propósito de apreender o significado da experiência de abrigo para crianças em idade escolar e identificar referências sobre sua auto-imagem em seus relatos.

Considerando os objetivos acima referidos, o método utilizado para desenvolver esta pesquisa foi de cunho descritivo e qualitativo. A escolha por este método deveu-se ao fato dele possibilitar a apreensão da realidade subjetiva de um grupo social. Para tanto, foram realizadas entrevistas com quatorze crianças em situação de abrigo. A organização dos dados permitiu identificar que o significado da experiência de abrigo está associado ao cotidiano, às relações com a família e com os cuidadores. Já a auto-imagem está associada à trajetória de vida, à visão do amigo, à imagem corporal e ao autoconceito.

Os relatos das crianças referentes ao significado da experiência de abrigo mostraram ambivalência de sentimentos em relação à instituição. Elas não reconhecem o abrigo como sua casa, contudo percebem que ele atende melhor as necessidades materiais do que suas famílias. Elas sentem que, no abrigo, são cuidadas e protegidas, têm melhores oportunidades de aprendizagem e maior acesso ao lazer. Gostam da instituição, mas desejam que essa situação seja transitória e que possam retornar para casa. Ao mesmo tempo em que os limites impostos pelas rotinas e normas permitem que elas se sintam cuidadas e protegidas, eles causam descontentamento devido às repreensões e falta de liberdade. 
Os relatos referentes à auto-imagem mostraram que todas as experiências vivenciadas pela criança refletem em seu autoconceito e que, apesar de seu histórico de violência familiar, elas buscam mecanismos de enfrentamento que as permitem desenvolver uma auto-imagem positiva em algumas áreas.

O estudo possibilitou compreender que não só a instituição exerce influência sobre a auto-imagem da criança, como esta também influencia a experiência de abrigo.

Palavras-chave: Criança Institucionalizada, Auto-imagem, Exclusão Social, Saúde Escolar. 


\section{ABSTRACT}

The experience of a child living in a shelter can hamper their development of a positive self-image when the shelter does not abide by the principles established in accordance with the law. Values, beliefs, images, attitudes and the entire set of information experienced in their childhood builds the image that the child has of them self. Therefore, it is necessary to study to what proportion the shelter, in its function as protection, contributes or not, to the formation of the child's self-image in situations involving personal and social risk.

If on one hand, the shelter situation can prevent or reduce damage to the child who, in their own intimate family environment was in a risk situation; it on the other hand, can cause setbacks to the child's formation of selfimage. Accordingly, the aim of this study was to learn the significance of such experiences in shelters for school-age children and to identify references about their self-images in their reports.

Considering the objectives herein stated, the method used to develop this research was of a descriptive and qualitative nature. The choice of this method should be the fact that it allows us to understand the subjective reality of a social group. With this in mind, interviews of 14 children in the shelter situation were performed. The organization of this data enabled us to identify that the significance of the shelter experience is associated with everyday life, with family relationships and with the primary caregivers. And self-image is associated with each life history, how one is viewed by friends, with body image and with self-opinion.

These children's reports, in regard to the significance of the shelter experience, showed an ambivalence of feelings toward the institution. They do not recognize the shelter as their home; however they understand that the institution meets their material needs much more than their own families do. They feel that at the shelter they are cared for and protected; have better opportunities for learning and higher access to leisure activities. They like the institution, but wish this situation were transitional with the possibility of returning to their homes. At the same time that the limits imposed by the routines and rules make these children feel cared for and protected, they also feel discontentment due to reprimands they receive and their lack of freedom. 
The reports regarding self-image showed that each and every experience lived by a child, reflects in their self-opinion and that, in spite of their history of family violence, they look for mechanisms to help them develop a positive self-image in some areas.

This study enabled us to understand that not only the institution exercises influence on the self-image of children, but also the influence of the shelter experience affects their self-image.

Key Words: Institutionalized Child, Self-image, Social Exclusion, School Health. 


\section{Sumário}

Apresentação

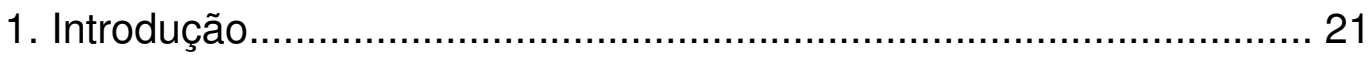

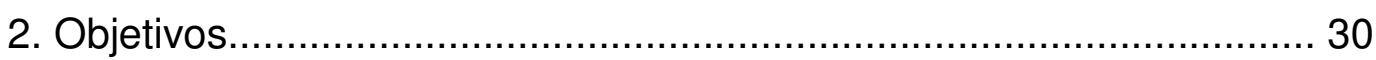

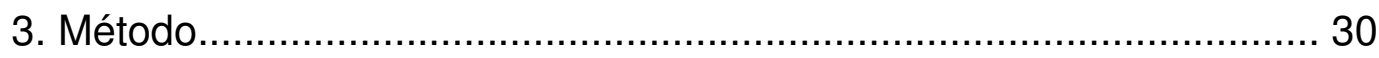

3.1. Referencial Metodológico.......................................................... 30

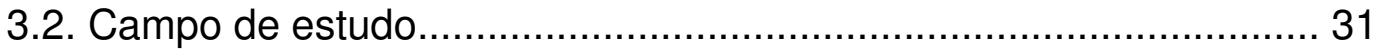

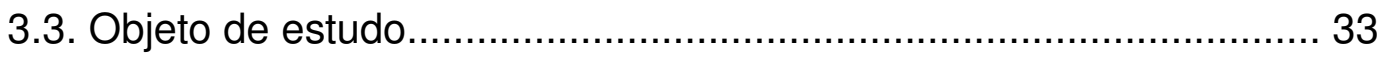

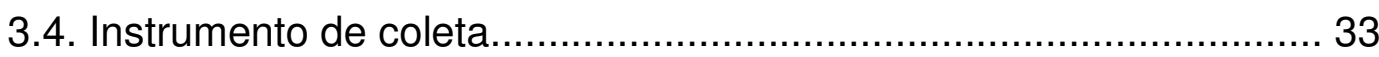

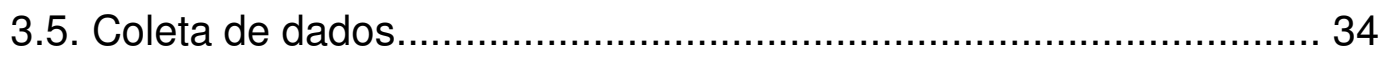

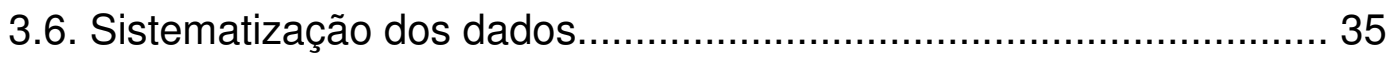

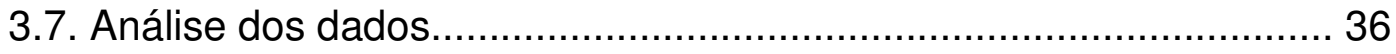

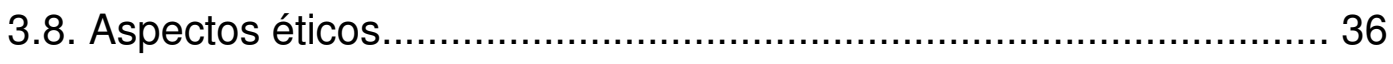

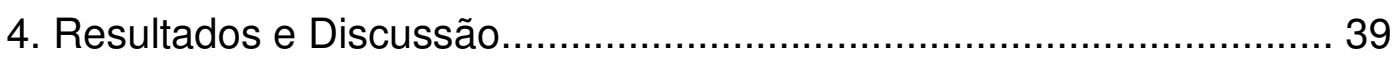

4.1. O significado da experiência de abrigo.............................................. 39

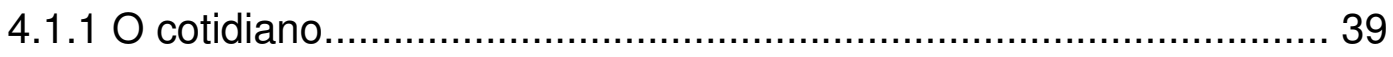

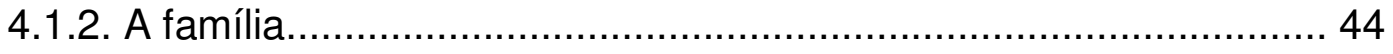

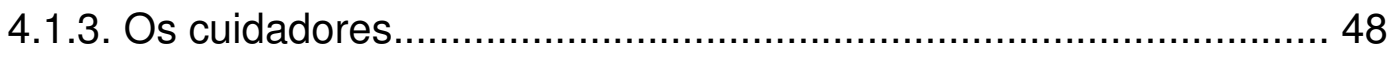

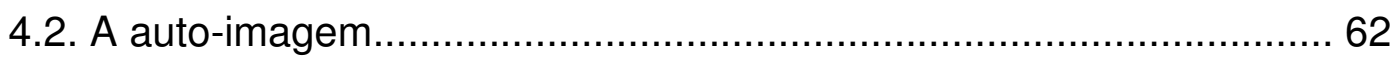

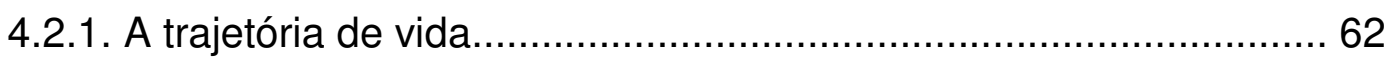

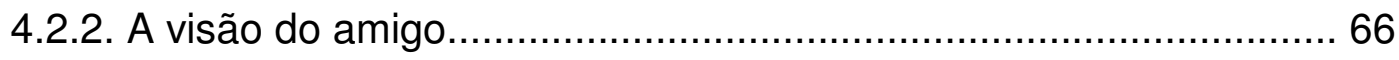

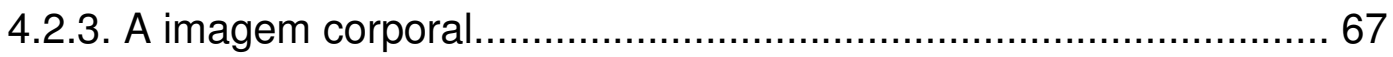

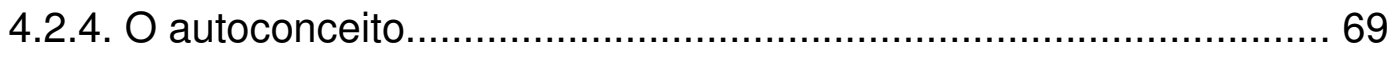

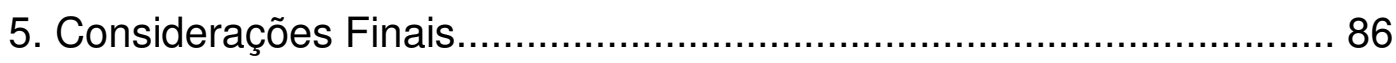

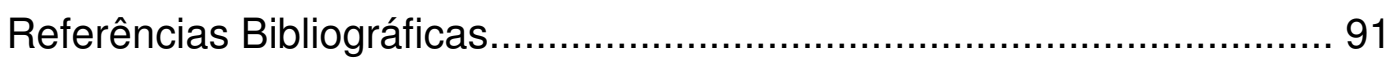

Anexos 


\section{Apresentação}

As injustiças sociais, sobretudo as que vitimizam crianças, sempre me interessaram e entristeceram, portanto ao ingressar na graduação do curso de enfermagem já estava claro para mim que eu me especializaria em saúde da criança. Esperei ansiosamente pela disciplina de pediatria, mas, ao iniciar os estágios da disciplina, causou-me grande tristeza e indignação a maneira desrespeitosa como crianças e familiares eram tratados nas instituições. Ingenuamente, naquela época, acreditava que aquele péssimo atendimento ocorria apenas porque se tratava de um hospital público. Mais tarde, já formada e atuando em um hospital da rede privada, descobri que, embora de uma maneira diferente, mais velada e menos agressiva, o descaso e o desrespeito pelos direitos da criança também ocorriam na rede privada. Percebi que isso acontecia devido à incapacidade da criança reivindicar seus direitos, ao fato das crianças dependerem do outro para respeitar e validar seus direitos.

A sociedade adultocêntrica ignora as necessidades da criança. Como cidadã, julgo pertinente valorizar a criança, direcionando as políticas públicas à criança e ao adolescente. Entretanto, a indiferença dos governantes e da sociedade civil para com a criança em situação de risco social e pessoal ultrapassa o limite da tolerância.

Quando decidi iniciar minha carreira acadêmica, passei a pesquisar assuntos sobre saúde da criança, durante essa pesquisa encontrei alguns (poucos) trabalhos científicos de enfermeiros sobre crianças em situação de risco social e pessoal, e decidi dedicar-me mais a esse assunto.

Conforme fui apreendendo as leituras, chamou-me atenção especial os relatos sobre as condições em que viviam as crianças nos abrigos, à violência a que muitas vezes eram expostas, à descaracterização de sua individualidade e conseqüente despersonalização.

Também, ao dialogar com colegas de enfermagem sobre o tema que eu pensava em escolher, espantou-me a surpresa com que recebiam minha 
escolha; achavam interessante, mas não conseguiam ver relação do tema com a enfermagem.

Ficou muito clara a necessidade de ampliar a discussão sobre o tema no âmbito da enfermagem, pois, com raras exceções, a criança em situação de risco social e pessoal não faz parte da grade curricular dos cursos de graduação em enfermagem. Nossa formação dá enorme ênfase a uma assistência hospitalar essencialmente técnica, excluindo uma assistência ampla que objetive o cuidar em todas as suas possibilidades.

Em contra partida, o artigo 227 da constituição brasileira prioriza a atenção à criança. Isso significa desviar o foco adultocêntrico para uma sociedade que valorize a criança. Nesse sentido, é imprescindível que a enfermagem se adapte a essa nova concepção. Isso implica rever seu currículo. Devido esse lapso em nossa formação, profissionais comprometidos com uma assistência de qualidade pecam, não por má vontade, mas por desconhecer a singularidade das crianças em situação de risco social e pessoal.

Considerando essa problemática, este trabalho tem a finalidade de sensibilizar os profissionais de saúde para a atenção à criança em situação de abrigo; e oferecer material acadêmico que possibilite a discussão e a visualização da inserção dos profissionais de enfermagem neste campo de atuação. 


\section{Introdução}

"Há um país chamado Infância, cuja localização ninguém conhece ao certo. Pode ficar lá onde mora o Papai Noel, no Pólo norte; ao Sul do Equador, onde não existe pecado; ou nas florestas da Amazônia ou na África misteriosa, ou mesmo na velha Europa. Os habitantes deste país deslocam-se em naves siderais, mergulham nas profundezas do oceano, caçam leões, aprisionam dragões. E depois, exaustos, tombam na cama. No dia seguinte, mais aventuras". Scliar (1989)

"Nem todas as crianças, contudo, podem viver no País da Infância. Existem aquelas que, nascidas e criadas nos cinturões de miséria que hoje rodeiam as grandes cidades, descobrem muito cedo que seu chão é o asfalto hostil, onde são caçadas pelos automóveis e onde se iniciam na rotina da criminalidade. Para estas crianças, a Infância é um lugar mítico que podem apenas imaginar quando olham as vitrinas das lojas de brinquedos, quando vêem TV ou quando olham passar, nos carros dos pais, os garotos de classe média. Quando pedem num tom súplice - tem um trocadinho aí, tio? - não é só o dinheiro que querem; é uma oportunidade para visitar, por momentos que seja, o país com que sonham". Scliar (1989)

Mas, por que não é possível manter todas as crianças no País da Infância? Quando o aparato estatal e a sociedade assumirão de fato, e de maneira efetiva, sua responsabilidade social em relação a essas crianças?

Não é possível responder a essas questões sem olhar para o passado e, assim, compreender os muitos erros cometidos. Ao longo da história, crianças foram abandonadas, abusadas e negligenciadas. $\mathrm{O}$ "cuidado" de crianças carentes e abandonadas no Brasil teve início somente a partir do final do século XVIII, com a implementação do sistema importado da Europa denominado "Roda dos Expostos". Inicialmente, as Irmandades (como as Santas Casas de Misericórdia) assumiram a responsabilidade por essas crianças. Carvalho (1993)

A Roda permitia que o expositor mantivesse $o$ anonimato. Essa foi a solução encontrada para evitar que crianças continuassem sendo 
abandonadas nas ruas, em lixos e florestas durante a noite e encontradas mortas pela manhã. Marcílio (2001)

Muitas crianças expostas eram entregues aos cuidados de "amas" que assumiam a incumbência de criá-las sob pagamento, pois eram raras as rodas que tinham condições de asilo para as crianças expostas. Em princípio, as amas ficavam com as crianças até a idade de três anos, mas eram estimuladas a manterem as crianças consigo para sempre. Nestes casos, prorrogava-se o pagamento até sete anos, e em algumas situações até doze anos. Após esse período era permitido explorar o trabalho da criança em troca de casa e comida, o que usualmente ocorria, ou sob a forma de remuneração. Marcílio (2001)

Devido às dificuldades financeiras, ao crescente aumento de crianças abandonadas e à incapacidade das Casas de Misericórdias em abrigar todas as crianças que voltavam do período de criação em casas de amas (uma vez que poucas aceitavam continuar com as crianças após o término do período em que recebiam salários), as crianças ficavam sem ter para onde ir e passavam a viver nas ruas, prostituindo-se, mendigando esmolas e praticando pequenos furtos. Essa situação levou a iniciativas, em algumas cidades, em busca de alternativas públicas e privadas. Começaram a surgir a instituições filantrópicas de proteção à infância desamparada; além disso, ordens religiosas de caridade fundaram asilos, orfanatos, patronatos e seminários por toda parte. Marcílio (2001)

Nestes locais, as crianças eram atendidas coletivamente e mantidas em regime de total isolamento, o que comprometia suas relações sociais, produzindo a despersonalização e lesão de sua auto-imagem, de sua identidade, além de favorecer abusos físicos, sexuais e psicológicos. Carvalho (1993)

"As crianças dos internatos eram estigmatizadas e privadas de viverem sua própria singularidade, cuja expressão desaparecia no coletivo institucional homogeneizado". Carvalho (1993) 
O Estado brasileiro demorou muito tempo para assumir a responsabilidade pelo atendimento de crianças em situação de risco social e pessoal e, quando decidiu fazê-lo, o fez para atender aos chamados delinqüentes, criando os Reformatórios e Institutos Correcionais com o intuito de proteger a sociedade dessas crianças e adolescentes. A partir da década de 70 , começam a surgir movimentos de mudança que exigem modificações na política desses sistemas isoladores e repressivos de atendimento. Graças a esses movimentos, foram criados creches e programas de atendimento a crianças carentes, como uma forma de prevenção à institucionalização, mas é na década de 80 , durante a transição democrática, que se dá à consolidação da luta por direitos que busca a extinção de toda e qualquer situação que impeça o desenvolvimento infantil sadio. Carvalho (1993)

Como conseqüência dessa luta em defesa dos Direitos Humanos, a Constituição Cidadã de 1988 inseriu em nossa sociedade os Direitos Internacionais da Criança, proclamados pela ONU em 1959. A Constituição, no artigo 227, determina que: "é dever da família, da sociedade e do Estado assegurar a criança e ao adolescente, com absoluta prioridade, o direito à vida, à saúde, ao lazer, à profissionalização, à cultura, à dignidade, ao respeito, à liberdade, à convivência familiar e comunitária, além de colocalos a salvo de toda a forma de negligência, discriminação, exploração, violência, crueldade e opressão" Brasil (1988). "Em obediência a essa determinação, foi elaborado e sancionado no Brasil, o Estatuto da Criança e do Adolescente (ECA) em 1990 (lei no 8.069 de 13.07.90), que entrou em vigor nesse mesmo ano". Westphal (2002)

Com o Estatuto da Criança e do Adolescente (1990) e a Lei Orgânica de Assistência Social (1993), o Estado assume finalmente a responsabilidade sobre a assistência à criança e ao adolescente abandonado, tornando-as sujeitos de Direito pela primeira vez na história. Marcílio (2001)

O ECA é uma legislação que dispõe sobre a proteção integral à criança e ao adolescente. Com o intuito de atender situações e problemas diversos, o ECA distingue medidas sócio-educativas de medidas de 
proteção. As medidas sócio-educativas são aplicadas unicamente a adolescentes infratores; já as medidas de proteção, referidas no artigo 98, destinam-se às crianças e adolescentes que tiveram seus direitos desrespeitados por: ação ou omissão do Estado; falta, omissão ou abuso dos pais ou responsável; e em razão de sua própria conduta. Brasil (1990)

"Na aplicação das medidas levar-se-ão em conta as necessidades pedagógicas, preferindo-se aquelas que visem ao fortalecimento dos vínculos familiares e comunitários”. Brasil (1990)

Isso está evidente no o artigo 101 do ECA onde se estabelece que, uma vez verificada qualquer das hipóteses previstas no art. 98, a autoridade competente poderá determinar outras medidas. O acolhimento em abrigo não é a única opção. É um dos recursos que pode ser utilizado quando se esgotaram todas as demais possibilidades e, ainda, em caráter temporário. Isso está claro no Parágrafo Único, onde consta que: "O abrigo é medida provisória e excepcional, utilizável como forma de transição para a colocação em família substituta, não implicando privação de liberdade". Brasil (1990)

As demais medidas compreendem, por exemplo: encaminhamento aos pais ou responsável mediante termo de responsabilidade; orientação, apoio e acompanhamento temporários; inclusão em programa comunitário ou oficial de auxílio à criança e ao adolescente; requisição de tratamento médico, psicológico ou psiquiátrico, inclusão em programa oficial ou comunitário de auxílio; e colocação em família substituta. Brasil (1990)

Uma das grandes virtudes do ECA é levar em consideração as etapas do desenvolvimento infantil e, conseqüentemente, priorizar medidas que preservem os laços afetivos e permitam o desenvolvimento de uma identidade positiva e uma auto-imagem saudável. Por essa razão, a colocação da criança em abrigo é a penúltima opção dentre as oito medidas de proteção.

É importante diferenciar abrigo, de albergue e internato. $\mathrm{O}$ abrigo foi implementado para substituir as instituições com elevado número de 
crianças reclusas, as "prisioneiras sociais". Trata-se de uma medida de proteção destinada às crianças abandonadas, vitimizadas, portadoras de deficiências físicas ou mentais e crianças infratoras. O responsável pelo abrigo é o guardião legal das crianças que ali residem, portanto abrigo é uma guarda institucionalizada. Embora o albergue também ofereça proteção, ele é um espaço utilizado por crianças, adolescentes e adultos, geralmente, moradores de rua, sozinhos ou acompanhados por suas famílias, para dormirem, tomarem banho e alimentarem-se. Caso a criança ou o adolescente esteja acompanhado da família, esta é a responsável legal, do contrário, o dirigente tornar-se o guardião. Já, a internação é uma medida sócio-educativa privativa de liberdade, destinada a adolescentes infratores.

Ao diferenciar "medida de proteção" (abrigo) de medida "sócioeducativa" (internato), o ECA visa proteger a criança e o adolescente não infrator, excluindo a existência do prisioneiro social.

O ECA também determina uma série de princípios que deverão ser seguidos pelas entidades que desenvolvam programas de abrigo: preservação dos vínculos familiares; integração em família substituta, quando esgotados os recursos de manutenção na família de origem; atendimento personalizado e em pequenos grupos; desenvolvimento de atividades em regime de co-educação; não desmembramento de grupos de irmãos; evitar sempre que possível, a transferência para outras entidades de crianças e adolescentes abrigados; participação na vida da comunidade local; preparação gradativa para o desligamento; participação de pessoas da comunidade no processo educativo. Brasil (1990)

Embora o ECA especifique claramente que abrigo é medida provisória e excepcional, uma pesquisa organizada pela Fundação Orsa e pela Secretária Municipal de Assistência Social (SAS) com a colaboração do NCA-PUC-SP (Núcleo de Estudos e Pesquisas sobre a Criança e o Adolescente da PUC/SP) e AASTJ/SP (Associação dos Assistentes Sociais e Psicólogos do Tribunal de Justiça de São Paulo), constatou existirem atualmente 4.847 crianças em 190 abrigos na cidade de São Paulo. Este trabalho avaliou 185 abrigos e 411 prontuários, uma amostra probabilística de $8,5 \%$ do total de crianças e adolescentes abrigados. Nessa amostra 
apurou-se que $67 \%$ possuem família e apenas $10 \%$ podem ser legalmente adotados. Além disso, o tempo de permanência das crianças nos abrigos ainda é longo, de um a dois anos (16,1\%) e de três a quatro anos (15,3\%). $E$ ainda, do total de abrigos da Secretária Municipal de Assistência Social (SAS), $09 \%$ deles atendem de 21 a 30 crianças e $91 \%$ atendem de 15 a 20 crianças. ${ }^{1}$

A experiência da criança/adolescente em situação de abrigo dificulta o desenvolvimento de uma auto-imagem positiva quando os princípios estabelecidos por lei são desrespeitados. A auto-imagem é construída no ciclo vital e é influenciada pelas relações interpessoais e interinstitucional que a criança vivencia. Os valores, as crenças, as imagens, as atitudes e o conjunto de informações vividas na infância e adolescência delineiam a imagem que a criança tem de si.

"O termo auto-imagem ou autoconceito inclui todas as noções, crenças e conviç̧ões que constituem um autoconhecimento individual e que influenciam as relações do indivíduo com outras pessoas. Ele não está presente ao nascimento, mas se desenvolve de maneira gradual como conseqüência de experiências únicas dentro de si mesmo, com outras pessoas significativas e com as realidades do mundo". O autoconceito "refere-se à sabedoria consciente de uma gama de autopercepções, como as próprias características físicas, capacidades (determinado pelo senso de produtividade), valores, ideais próprios, expectativas e uma idéia de si mesmo em relação aos outros. Isto também inclui uma imagem do próprio corpo, a sexualidade e a auto-estima". Wong (1999)

$O$ fato em si de pertencer a um abrigo pode influenciar a auto-imagem da criança/adolescente. A Comissão Conjunta sobre a Saúde Mental de Crianças "chamou a atenção para os efeitos prejudiciais que a pobreza e a discriminação (que freqüentemente aparecem juntas) podem ter no ajustamento psicológico e na auto-estima de crianças e adolescentes. Um indivíduo que se perceba pertencendo a um grupo passível de ser tratado

${ }^{1}$ Dados encontrados no site:

Http://Pucsp.Br/Publique/Cgi/Cgilua.Exe/Sys/Star.Htm?Infoid=455\&Sid=172 (21/03/2005). 
discriminatoriamente, é visto de modo degradante pela maioria das pessoas de uma sociedade, pode tornar-se compreensivelmente ressentido e amargo". Mussen, Conger, Kagan (1977)

"As crianças em idade escolar estão mais cientes da diferença entre as pessoas, são mais sensíveis às pressões sociais e se tornam mais preocupadas com questões de autocrítica e auto-avaliação". Cada pequeno sucesso aumenta a auto-imagem da criança e a impele a tentar ter sucesso novamente, já as experiências de fracasso levam a dúvida sobre si própria. Wong (1999)

A questão principal consiste em saber se a situação de abrigo constitui experiências construtivas ou não à auto-imagem da criança em situação de risco pessoal e social. Segundo um estudo realizado com crianças abrigadas, sobre "alterações cognitivas em escolares de classe sócio-econômica desfavorecida", identificou-se que a representação da imagem corporal de $38 \%$ delas era deficiente. Utilizando-se o teste da figura humana de Goodenough, os autores constataram alteração da imagem corporal das crianças em relação ao esperado para suas idades cronológicas, provocadas por deficiências cognitivas específicas: percepção viso-motora, percepção de forma e "perseveração" (perseverança). Macedo; Andreucci; Montelli (2004)

Se, por um lado, a situação de abrigo pode implicar prejuízos na formação da auto-imagem da criança, por outro, pode evitar ou reduzir danos à criança que, no seio da família, se encontrava em situação de risco. Assim sendo, em que medida o abrigo, em sua função de proteção, contribui para a formação da auto-imagem da criança nessa condição social? Tão importante quanto atender as necessidades físicas da criança em situação de abrigo é atender suas necessidades psicossociais, entre as quais, a percepção de si mesma e do ambiente em que vive.

Após 15 anos da implementação do ECA, onde se estabeleceu que os abrigos deveriam restringir o número de crianças para evitar a massificação de sua identidade, novos estudos são necessários para se avaliar os efeitos dessas mudanças. 


\section{Objetivos}

Com o intuito de atingir essa meta, esse estudo tem o objetivo de:

- $\quad$ Apreender o significado da experiência de abrigo para a criança em idade escolar;

- Identificar, no relato da criança em situação de abrigo, referências sobre sua auto-imagem.

\section{Método}

\subsection{Referencial metodológico}

Considerando os objetivos acima referidos, o método utilizado para desenvolver esta pesquisa foi de cunho descritivo. Tendo em vista que o estudo em questão busca apreender a experiência e as referências subjetivas de um grupo social específico, portanto numa abordagem psicossocial, foi necessário utilizar um método capaz de identificar opiniões, atitudes e crenças da população estudada.

A pesquisa foi desenvolvida tendo em vista também o método qualitativo. A escolha por este método deveu-se ao fato dele possibilitar a apreensão da realidade subjetiva de um grupo social. Esse recurso foi pertinente para a atual pesquisa porque permitiu que as crianças envolvidas fossem porta vozes de seu grupo e exprimissem sua representação social. Nessa perspectiva, a Representação Social está sendo compreendida como:

"a reprodução de uma percepção anterior ou do conteúdo do pensamento. As representações de um indivíduo não são necessariamente conscientes. Perpassam o conjunto da sociedade ou de determinado grupo social, como algo anterior e habitual, que se reproduz e se modifica a partir das estruturas e das relações coletivas e dos grupos". Minayo (2004)

"a representação implica na ação, na experiência com um objeto ou situação e nos significados atribuídos a ela pelas pessoas com que nos relacionamos, ou seja, a representação é o sentido pessoal que atribuímos aos significados elaborados socialmente". Lane (1983) 


\subsection{Campo de estudo}

Foram selecionados abrigos que estavam registrados no Conselho Municipal, órgão responsável pelo cadastro e regulamentação dessa entidade. A partir de uma listagem de 27 abrigos identificados através de um "levantamento sobre os serviços de saúde às crianças carentes nos abrigos na cidade de São Paulo", Delgado, Ribeiro (2002), foram realizados contatos telefônicos com 24 deles. Nesses contatos, era explicado o propósito do estudo ao responsável e questionado sobre a possibilidade de se realizar a investigação no respectivo local. Somente dois abrigos aceitaram participar da pesquisa.

Após essa etapa, procedeu-se a entrega do projeto de pesquisa aos diretores das instituições, junto com uma carta de apresentação (Anexo 1). Em seguida, realizou-se uma reunião, com cada responsável, que resultou na autorização para a iniciação da coleta de dados.

Entretanto, surgiu uma intercorrência. O diretor do abrigo B ausentouse por quinze dias e solicitou à pesquisadora que lhe deixasse os termos de consentimento para serem por ele assinados após seu retorno. Conforme acordado, cinco entrevistas foram realizadas e transcritas nesse intervalo de tempo. No entanto, após seu retorno, desistiu de assiná-los, alegando por meio de um interlocutor que "criança não consente nada". Embora tenha se recusado a assinar os termos de consentimento, manteve sua autorização (verbal) para a inserção das entrevistas no estudo. Porém, tendo em vista o compromisso da pesquisadora e sua fidelidade aos princípios éticos, os relatos das crianças não foram incorporados no presente trabalho.

O abrigo A é uma entidade privada sem fins lucrativos, com 82 anos de existência. A instituição desenvolve programas de abrigo e de apoio sócio-educacional.

O programa de abrigo atende setenta e duas crianças em situação de risco social e pessoal. As crianças atendidas são da faixa etária de quatro a doze anos para os meninos e de quatro a dezoito anos para as meninas. Elas são admitidas quando estão na faixa etária entre quatro e oito anos. $O$ 
programa de apoio sócio-educacional atende 120 crianças, no período da manhã ou tarde, alternando com os horários de aula do ensino formal, de segunda a sexta-feira. Atende crianças (meninos e meninas) de quatro a dezesseis anos. Para a admissão neste projeto, a criança precisa ter entre quatro e doze anos.

A instituição possui cerca de oitenta e cinco funcionários, distribuídos entre as áreas administrativa e técnica. Esta última é composta por psicólogos e assistentes sociais. O trabalho desenvolvido por eles consiste em avaliar cada caso e elaborar pareceres para subsidiar a decisão jurídica. Além disso, realizam um projeto denominado "família participativa" que atende as famílias das crianças abrigadas, visando o retorno do abrigado para sua família. Os educadores são responsáveis pelas atividades educativas e os cuidadores atendem as necessidades de rotina das crianças. A instituição também conta com um corpo de quarenta voluntários que realizam trabalhos pedagógicos, de assistência psicológica e fonoaudiológica, e recreação.

A área física é composta por dormitórios, refeitório, salas de aula, biblioteca, sala de informática, oficinas (costura, artesanato, panificadora, etc), auditório, capela, quadra de esportes, playground e prédio administrativo. Existem dormitórios (chamados de casa pelas crianças) separados para meninos e meninas. Neles, além dos quartos, que possuem armários exclusivos para cada criança, há uma sala de TV, uma pequena cozinha e banheiros.

O cotidiano das crianças envolve: cuidados básicos de higiene; alimentação e repouso; educação formal (EMEI, EMEF e EM) e complementar (reforço escolar, esportes, dança, música); oficinas/cursos profissionalizantes (costura, informática, turismo, manicure cabeleireiro entre outros); atendimentos de saúde (psicológico, terapia ocupacional, odontológico, fonoaudilógico) e passeios recreativos e culturais.

\subsection{Objeto de estudo}


O objeto de estudo desta pesquisa foi crianças em idade escolar (de 6 a 12 anos) que viviam em situação de abrigo na cidade de São Paulo. Considerando os preceitos estabelecidos pelo ECA, a criança está em situação de abrigo quando o tempo de moradia, em um ou mais abrigos, é superior a seis meses.

\subsection{Instrumento de coleta}

O principal instrumento para se obter a representação social de um indivíduo ou grupo social é o discurso, pois, por meio deste, os indivíduos expressam conceitos, idéias e contradições construídas historicamente, agregadas às experiências vivenciadas nas relações sociais. Isso significa que a representação subjetiva é uma construção social.

Partindo deste pressuposto, os dados foram coletados por meio de entrevistas individuais concedidas à pesquisadora.

"O que torna a entrevista instrumento privilegiado de coleta de informações para as ciências sociais é a possibilidade de a fala ser reveladora de condições estruturais, de sistemas de valores, normas e símbolos (...) e ao mesmo tempo ter a magia de transmitir, através de um porta-voz, as representações de grupos determinados, em condições históricas, sócio-econômicas e culturais específicas". Minayo (2004)

A criança em idade escolar tem capacidade de comunicar-se por meio da linguagem oral, numa seqüência narrativa lógica e cronológica. Já possui competência para relatar sua representação de mundo e a compreensão da realidade subjetiva. O desenvolvimento cognitivo, Piaget (1979), da identidade ,Erikson (1971) e da formação moral, Kohlberg apud Mahon, Fowler (1979) \& McCown (1984), iniciam-se nos primeiros anos de vida, mas é durante a fase escolar que esses três processos adquirem caráter próprio. A criança passa a pensar, agir e expressar seus pensamentos de acordo com sua própria consciência, seu próprio julgamento. A aquisição dessa habilidade permite a construção de sua própria representação social.

\subsection{Coleta de dados}


Embora o escolar seja capaz de expor seu pensamento numa narrativa lógica, apresenta dificuldade em expressar seus sentimentos. Por isso, o desenho dirigido foi um recurso utilizado nas entrevistas para auxiliálo a expressar seu pensamento. Assim, foi solicitado às crianças que fizessem um desenho delas mesmas e do local onde vivem e que narrassem uma história sobre o desenho. Essa estratégia consistiu no instrumento de comunicação com as crianças.

"O desenho é uma das formas mais valiosas de comunicação - tanto não verbal (análise do desenho) quanto verbal (construção da história do desenho da criança). Os desenhos das crianças dizem muita coisa a respeito delas porque constituem projeções de seus interiores”. Wong (1999)

Desse modo, a coleta de dados consistiu, inicialmente, no discurso narrativo da criança em relação ao seu desenho. As entrevistas iniciavam com uma solicitação como "fale-me sobre o(a) menino(a) e a casa que você desenhou" e continuavam com diálogos espontâneos. O desenho foi uma estratégia utilizada para desencadear e facilitar a narrativa da criança. Durante a entrevista, ocorreram intervenções da pesquisadora com o intuito de estimular as crianças a continuarem falando, a esclarecer pontos obscuros e para obter maiores informações sobre o tema abordado. Tais perguntas surgiram do próprio contexto da narração e somente foram formuladas quando as crianças demonstravam disposição em continuar a participar da investigação, mas esperavam que a pesquisadora fizesse perguntas mais específicas. Além disso, as perguntas foram elaboradas tendo o cuidado de não induzir respostas.

Antes de iniciar a coleta dos dados, estabeleceu-se um dia para contato prévio informal com as crianças de cada abrigo com a finalidade de criar vínculo de confiança. Porém, no início de cada entrevista, procedeu-se a apresentação formal da pesquisadora às crianças (Anexo 2), a leitura do Termo de Consentimento Livre e Esclarecido (Anexo 3) e a assinatura deste pelas crianças.

O número de crianças participantes não foi previamente estabelecido. A coleta foi limitada em função do tempo e da disponibilidade da 
pesquisadora, conforme cronograma do projeto de pesquisa. Nele, estava previsto um intervalo de tempo de dois meses dedicados à coleta e foram necessários para isso dez períodos de aproximadamente seis horas. A definição das crianças participantes da pesquisa foi aleatória. As incluídas foram aquelas que se aproximaram da pesquisadora, durante o contato informal, manifestando explicitamente seu interesse. Foram excluídas somente aquelas que não correspondiam ao limite de idade. Assim, foram realizadas quatorze entrevistas no abrigo $A$ (dez meninas e quatro meninos) e cinco no abrigo $B$ (três meninas e dois meninos).

As entrevistas não tiveram tempo de duração pré-determinado. Foram encerradas quando as crianças diziam não ter mais o que contar, ou quando a pesquisadora percebia gestos que demonstravam cansaço e dispersão, ou ainda, quando deixava de atingir seu propósito. De modo geral, as entrevistas duraram de vinte a quarenta minutos.

\subsection{Sistematização dos dados}

As narrativas foram gravadas e transcritas na íntegra para que se pudesse proceder a sistematização dos relatos transcritos e, posteriormente, sua análise.

Após a transcrição das entrevistas, o texto discursivo foi sistematizado de acordo com as regras de modalidade temática da Análise de Conteúdo. Minayo (2004)

O material foi organizado com o fim de obedecer a algumas normas de validade: "exaustividade" (leitura e releitura do texto transcrito para identificar os temas abordados); "homogeneidade" (agrupamento dos temas por afinidade de idéias); "representatividade" (formação de categorias de representação do universo); "pertinência" (analise dos documentos em relação à adequação dos objetivos do trabalho). Minayo (2004)

A sistematização dos dados, então, consistiu na exploração do material, onde as unidades de registro foram classificadas, agregadas e relacionadas com as respectivas unidades de contexto dos temas predominantes. Determinou-se a unidade de registro (palavras chave ou 
frases), a unidade de contexto (compreensão da unidade de registro), os recortes, a forma de categorização e os conceitos teóricos gerais para a análise. Assim, os resultados foram organizados, destacando as informações obtidas conforme a relevância dos temas. Minayo (2004)

Desse modo, as categorias geradas a partir da sistematização dos textos transcritos, foram agrupadas de acordo com seu sentido e significado em relação aos demais discursos, gerando os temas: o Significado da experiência de abrigo e a Auto-imagem.

\subsection{Análise dos dados}

Devido ao fato deste estudo basear-se em uma abordagem psicossocial, os referenciais teóricos que fundamentaram a análise foram pautados em autores que reconhecem a determinação social nas relações pessoais e nas concepções que o indivíduo constrói sobre si e o outro.

\subsection{Aspectos éticos}

O projeto foi submetido e aprovado pelo Comitê de Ética da Escola de Enfermagem da USP. Uma vez aprovado, procedeu-se a assinatura do Termo de Consentimento Livre e Esclarecido (Anexo 3) pelas crianças participantes e pelo seu guardião. Neste termo, constavam esclarecimentos sobre o objetivo da pesquisa, a gravação da entrevista em fita cassete, o sigilo de sua identidade e o respeito ao direito de desistir a qualquer momento da pesquisa.

Para garantir o sigilo da identidade das crianças participantes deste estudo, os relatos não possuem qualquer tipo de identificação, nem mesmo nomes fictícios, porque, ao se relacionar os fatos relatados, haveria o risco de identificação das crianças, dado o teor pessoal de suas falas. 


\section{RESULTADOS E DISCUSSÃO}

A sistematização dos dados gerou duas grandes categorias: a "autoimagem" e o "significado da experiência de abrigo".

\subsection{O Significado da Experiência de Abrigo}

A organização dos dados permitiu identificar que o significado da experiência de abrigo está associado ao cotidiano no abrigo, às relações com a família e com os cuidadores. Assim, esta categoria foi desmembrada em três subcategorias: o cotidiano, a família e os cuidadores.

\subsubsection{O cotidiano}

No que se refere ao abrigo, as crianças lhe fazem referências deixando perceber que não o consideram sua casa. No entanto, reconhecem que o abrigo atende suas necessidades materiais e de proteção, predicados que normalmente são da família. A rotina, as regras e os castigos lhes causam mal-estar, mas são vistos como necessários. As relações com os colegas estão muito presentes nos relatos. Estes elementos influenciam a maneira como as crianças percebem, reagem e significam seu cotidiano no abrigo.

\section{A) $\underline{O}$ abrigo como um colégio interno}

As crianças entrevistadas demonstraram em suas falas, de forma explícita ou implícita, que não consideram o abrigo sua casa. Para elas, o abrigo é um colégio interno. Afirmam gostar da instituição, mas deixam transparecer o desejo que esta situação seja transitória e de poder retornar para casa, apesar da condição de miséria, da negligência e da violência familiar presente em sua trajetória. Para elas, sua casa é onde a família está. Algumas crianças ressentem-se da falta de liberdade no abrigo, mas reconhecem que estão mais seguras na instituição.

Eu quero sair daqui. Eu queria ir embora toda semana para minha casa.

Depois voltar e ficar aqui. 
Eu gosto daqui, mas eu queria tá na minha casa. Eu gostaria que meu pai e minha mãe morasse comigo, mas por enquanto eu vou ficar aqui porque o juiz não me deixa ir embora. Mas, eu queria tá na minha casa! (disse de modo enfático) Eu gosto de brincar com meus irmão... eu gosto de brincar na rua, mas na rua é mais perigoso do que aqui, porque tem ladrão.

Eu gosto daqui por causa que é muito legal, o colégio é legal e as tia também, né.

Se eu tivesse que escolher outro lugar pra morar e o lugar fosse na minha casa eu escolhia na minha casa, se fosse outro abrigo, escolhia aqui, porque minha vida aqui é legal, minhas amigas, os amigos, os passeio, as tias, a casa, a quadra, o parquinho, a escola, minha professora.

Assim... não é que eu não goste daqui, mas eu não vejo a hora de sair daqui, é porque qualquer um não vê a hora de sair daqui, poder trabalhar, fazer alguma coisa na vida, poder ver minha mãe, fazer um monte de coisa, a gente vai pra muito passeio, a gente sai daqui de vez em quando, mas é melhor viver a nossa vida, ter minha casa, minha família, viver minha vida, ser o que eu quero ser do que ficar aqui direto, preso.

\section{B) As necessidades materiais e de proteção}

Nos relatos, as crianças mostram que têm consciência de que 0 abrigo atende melhor suas necessidades materiais do que a família. Elas sentem-se cuidadas e protegidas. Elas também percebem que suas oportunidades são maiores. Toda criança sente necessidade de ser protegida e amparada por sua família, do contrário, percebe-se vulnerável. Quando a família falha, sente-se insegura para enfrentar os desafios que a sociedade lhe impõe. Por isso, o abrigo é visto pelas crianças entrevistadas como um lugar que supre necessidades que a família não consegue atender.

Eu desenhei a escola. Eu quis desenhar só a escola. Eu não quis desenhar o lar (o abrigo), porque eu não gosto.

Eu gosto de morar aqui. A minha vida aqui é boa, legal, porque eles tão cuidando da gente. Dá roupa, dá brinquedo, só.

Eu tô estudando aí...(longo silêncio)... e eu não sei mais... O que tem de bom aqui é tomá banho, comê, escola... às vezes nós vamo pro passeio.

Ah! Aqui tem algumas atividades muito legal. Pode aprender, você pode conseguir o que você quiser. Lá fora, você não pode ter toda a segurança que tem aqui dentro. Ah, minha vida aqui é boa, é legal, eu me acostumei aqui.

Eu gosto de morar aqui. Melhor do que eu ta lá sofrendo. Eu gosto de tudo aqui, a minha vida aqui é boa. Porque eu tenho tudo que eu quero aqui. Eu quero que a minha vida seja boa onde for. (...) Aqui é um lugar bom, eu nunca posso dizer nada mal daqui. 
Morar na sua casa é melhor do que morar aqui ou não?

Um pouco não e um pouco sim. É bom ter minha mãe, meu pai, ficar com meus irmão, ficar na minha casa, mas é pior quando minha mãe bate na gente, quando nós não tem proteção. Só.

Acho que eu vou sair daqui com uns 16 ou 17anos, vou morar no Rio de Janeiro junto com minha mãe e minhas irmãs. É difícil a gente ter nossa vida né, aqui a gente estuda, tem atividade, joga futebol, aprende um monte de coisa na padaria, na aula de pintura, assim... essas coisas... a gente pode ser muita coisa na nossa vida, né.

A vida aqui é boa, porque os outros me tratam como meu pai e minha mãe.

\section{C) A rotina, as regras e os castigos}

No abrigo, as crianças vivem o dia a dia permeado por horários e regras que, quando são descumpridos, geram repreensão ou castigo. Ao serem questionadas sobre como era sua vida no abrigo, algumas relataram sua rotina e o que Ihes ocorria quando desrespeitavam as regras. Embora as crianças estabeleçam o elo entre causa e efeito, isto é, reconheçam que foram punidas por um comportamento inadequado, elas revelam o mal-estar que sentem ao serem repreendidas ou castigadas. É importante ressaltar que, mesmo desobedecendo e reclamando, as crianças necessitam de limites e esperam que os adultos estabeleçam normas de comportamento, pois entendem a repreensão e o castigo como uma demonstração de cuidado e preocupação. Provavelmente, este procedimento é um dos fatores que faz com que as crianças sintam que o abrigo supre necessidades que a família não consegue prover.

Não tenho nada pra contar daqui. Mandam a gente pro reforço. Levam também pra escola, que é aqui pertinho. Levam a gente pro parquinho, deixa nois brinca. Também tem catequese. Tem dança. De sábado e domingo, abre o auditório pra nois vê musical ou filme. Em dia de chuva, nois fica dentro da casa. E, depois do café, tem almoço. Depois do almoço, vem o lanche da tarde. Depois vem a janta.

Eu tava brincando, depois a tia chamou nós pra dentro da casa, aí nós tomamo banho. Não! Primeiro nós vamo na janta, depois nós vamo tomar banho. Aí depois nós vamo assisti TV, aí depois a tia dá lanche à noite pra nós não ficar com fome à noite. Aí depois nós vamo durmir, aí depois nós vamo pra escola, aí nós vamo pra sala de aula fazer a lição. Pronto.

É legal, quando a tia fala assim "entra pra casa". Aí nois tem que entrar. Se a pessoa não entrar, ela põe no livro e manda dormir cedo. Aí, o livro vai pro escritório ou a tia conversa com a menina, mas se a menina fizer uma coisa muito grave, aí a menina fica de trabalho educativo. 
Eu gosto das tarefas só às vezes, porque na hora que nós limpa a casa, dá raiva.

Eu não gosto quando as tias brigam comigo, quando a gente faz bagunça, fica batendo nos outro, aí elas brigam.

O que eu não gosto é a bronca. É... eu fico zoando aqui em baixo, aí a tia fala pra eu subi, aí eu fico brincando e a tia me coloca de castigo e eu tomo bronca.

Que castigo você recebe?

Fico limpando mezinhas ou limpa dentro da casa e fico sem lanche.

Eu gosto de morar aqui, eu gosto de ir no parquinho, jogar bola. Eu não gosto de ficar desobedecendo as tia, porque aí eu fico de castigo no trabalho educativo, tenho que dormir cedo, não posso assistir tv e não vou pro passeio.

Como você sente quando fica de castigo?

Mal, fico nervoso, bagunço.

Eu só não gosto de levar bronca quando eu faço bagunça, subo no muro, no telhado pra pegar manga e só.

\section{D) As relações com o grupo}

As relações com o grupo mostram-se complexas no abrigo. Os relatos revelam que as amizades são importantes para a adaptação das crianças pois, à medida que se socializam com as outras crianças, suas vidas tornam-se melhor na instituição. Em contra partida revelam também ser um problema quando se misturam com "más companhias"; ou seja, para serem aceitas, as crianças se vêem obrigadas a ter um comportamento igual ao do grupo para manter essa rede de relações. Mas, quando são punidas por comportamentos considerados inaceitáveis, elas se sentem culpadas e arrependidas. Esses sentimentos refletem a maneira como avaliam sua vida no abrigo. Elas acreditam que o abrigo propicia contato com as "más companhias". Além disso, a rotatividade dos colegas parece incomodar as crianças, pois são obrigadas a romper vínculos afetivos. Outro fator de insatisfação são as brigas e agressões que ocorrem.

Uma moça me trouxe pra esse colégio, daí eu fiquei nessa casa e fiz bastante amiga, depois quem entrou foi a $R$. Não, aí depois quem entrou foi a $N$. A N. falou pra mim que entrou outra menininha careca que era a $R$., aí eu e a N. falamos assim "você quer entrar no nosso grupo"? Ela falou assim "tá bom, nosso grupo vai ser o grupo das carequinha" (risada).

Eu tô no lar... brincando sozinha e todo mundo tá dentro da casa assistindo TV. Tô brincando... brincando com... Eitá! Esqueci de... posso desenhar uma pessoa? Porque senão eu vou ficar sozinha. Eu só vou 
desenhar uma amiga que eu tenho. Agora eu tô no lar brincando com minha amiga. Minha vida aqui é legal porque eu tenho amigos. Só isso.

No começo eu não gostei não, sabe, na minha casa eu tinha um monte de amigas. Conversava com elas. Aqui no lar, quando eu entrei, eu não conversava com ninguém. Ninguém dava bola pra mim, aí eu e a minha irmã tava no parquinho, aí veio duas menina, aí começaram a conversar com a gente, aí depois elas entrosaram a gente com as outras pessoas, aí nós começamos a ficar amiga de todo mundo.

Eu, ao mesmo tempo gosto e não gosto. Às vezes não tem nada pra mim fazer, às vezes fica legal e às vezes tá chato. É legal quando eu fico com as minhas amigas, quando eu brinco com elas, e fica chato quando não faço nada.

Minha vida é feliz, porque eu converso com meus amigos.

Esse desenho representa minha felicidade, representa tudo que tem aqui, as pessoas boas. Eu sou essa aqui, eu não sabia nada, aí eu fui pra escola e aprendi muitas coisas legais. Quando minhas amigas chegavam da escola eu perguntava "pra onde vocês foram?", "Fomos pra escola". Aí eu falei "também quero ir", aí a tia falou "você vai amanhã". Eba! Aí de repente, chegou o dia seguinte e eu fui pra escola. Gostei muito de estudar, eu conheci uma professora muito legal. Depois, de repente, comecei a achar um saco, aí depois meu amigo D., que senta do meu lado, chegou e queria pular muro. Aí eu ia junto. Assim foi minha história quando entrei aqui. Depois disso, até 2003 eu gostava de bagunça, aí chegou 2004, minha amiga saiu do lar e eu não quis mais saber de bagunça, e até hoje eu não bagunço mais. Fazer o que?... Eu queria que voltasse aquela época, que eu bagunçava. .Era legal.

E agora não é mais legal?

Não tanto como antes. Antes tinha meus amigos que saíram do lar, eu ainda tenho alguns aqui, só que eu sinto falta de antigamente. Eu queria que voltasse aquela época dos meus amigos legais.

Minha vida aqui é horrível! Porque quando se vem pra um lugar com um monte de gente e depois quando vai na dos outros, você fica se sentindo culpada. A tia leva todo pessoal pro escritório, faz uma reunião. Por isso, agora eu não vou embora. Eu e as menina tava baguçando, aí eu entrei e vi as menina pegando dinheiro. Aí eu falei pra tia. Ela falou "vocês vão se ferrar, tá". Aí eu falei "tia, eu não tava, eu não tava". Aí a tia não quis acreditar e colocou meu nome no papel. Aí a tia do escritório falou "todos vocês vão fica sem ir embora". Daí eu falei "a gente também?" Aí ela falou "se você tá aqui, é porque participou". Mas eu falei "eu não participei de nada". O que eu não gosto aqui é das menina que fica levando eu pro mal caminho.

A vida aqui é boa, médio, é muito legal. Mas só que, quando eu me misturo com as menina malcriada, elas me leva pro mau caminho, eu pulo o muro, pego coisa de pessoa, não me controlo. Um dia, faz tempo, eu tava mexendo no armário das menina pra pegar coisa, batom, perfume, shampoo, creme, dinheiro. Quando eu via dinheiro no chão, eu pegava e não perguntava de quem era, mais agora, eu não sou mais assim. Um dia, uma menina viu eu passar o perfume dela. Um dia, eu tava pra pegar a bolsa dela, mas a tia viu e pediu pra deixar a bolsa dela. Aí a tia me levou pro negócio e deu passe de ônibus pra mim, pra eu não mexer mais no armário das menina e me controlar, por 
causa que eu posso me ferrar, posso ser presa, ir pra delegacia, pra FEBEM. Aí eu posso ficar sem o meu pai e minha mãe. As menina daqui leva nois pro mau caminho. O que eu não gosto é de fazer coisa errada aqui, de desobedecer. Eu to arrependida de fazer coisa ruim, xingar as pessoa, bater.

Eu já fiquei no trabalho educativo uma vez, por causa que uma menina tirou sangue de mim, aí eu mordi ela e aí ela mordeu eu mais. Aí tirou um pouco da minha pele e começou a sangrar. Aí minha irmã bateu nela também.

Se eu tivesse que escolher um lugar pra morar, eu escolhia o abrigo. Se eu não gostasse, eu escolhia a casa do meu pai e, de vez em quando, eu ia pra casa da minha irmã. Eu prefiro morar aqui, mas quando não tem briga, porque minha irmã me bate. Ela só me bateu um dia. Minha vida aqui é triste quando as pessoas fazem coisa errada. Eu gosto de morar aqui, mas eu não gosto das briga.

Tem muita briga aqui?

Tem. Porque uma mexe no armário da outra, aí a outra fica com raiva e bate. Um dia, a menina cortou a mão da minha irmã. Eu amo todo mundo daqui do lar, eu adoro os outros, eu odeio mais as... (cita os nomes de algumas crianças) que só me bate, briga comigo.

Me deixa triste ficar ameaçando, bater nos meus amigo.

\subsubsection{A família}

Quanto à família, as crianças fazem relatos sobre a separação dos irmãos, a expectativa de ir para casa, as visitas dos familiares, a perda do vínculo com os pais e aos sentimentos relacionados à separação. Através de seus relatos, foi possível apreender que a família é o centro do afeto e das preocupações das crianças e que ela influencia o significado da experiência de abrigo.

\section{A) A separação dos irmãos}

Embora o ECA determine o não desmembramento dos grupos de irmãos, quando afastados dos pais, as falas das crianças demonstram que isso não ocorre. Várias situações colaboram para isso. $\mathrm{Na}$ maioria dos casos, os pais mantiveram a guarda de alguns filhos e perderam a de outros, os que foram encaminhados ao abrigo. Uma família de seis irmãos foi desmembrada. Três irmãos foram para uma instituição e os demais para outra. Algumas crianças relataram não saber onde um dos irmãos se encontrava. Esta situação prejudica o desenvolvimento das crianças, uma vez que são obrigadas a romper vínculos afetivos. Brasil (1990) 
Eu tenho sete irmãos, eu tinha duas aqui, agora eu só tenho uma, porque ela fugiu e eu não vejo mais ela. Os outros estão em casa porque eles são bebê.

O E. tá na casa do meu padrasto que matou a minha mãe. Eu e o M. fica aqui e com minha vó.

Meus irmão mora num abrigo longe. Eu vejo eles. As tias deixam visitar os irmãos. (Ela tem duas irmãs vivendo com ela e três irmãos vivendo em outro abrigo). Eu vejo eles quase todo dia. A tia leva pra visitar os irmão.

Tenho quatro irmãos, mas tenho outro que tá lá no hospital, no outro canto.

Tenho cinco irmãos, dois tá aqui e três com a minha mãe.

Tenho cinco irmãos, comigo seis. Tem duas aqui e os outro tá em outro colégio (outro abrigo).

Eu tenho um irmão comigo, dois com o $C$, três com a $G$, quatro com o $D$, cinco com a J. Meus irmãos estão num abrigo, sei lá, e tem a Gl. também.

Eles estão em outro abrigo, é isso?

Não, o D. sumiu, meu pai e minha mãe não sabem onde ele está. $A \mathrm{~J}$. tá com a A., a Gl. tá com a minha mãe e a G. e o C. estão aqui.

Minha mãe tem sete filhos. Aqui no lar fica eu e a minha irmã mais nova. Minha irmã mais velha fugiu do lar. Ela já tava planejando desde do outro dia. No dia que ela ia fugir, ela deu um beijo em mim e na outra irmã. Nós perguntamos o que aconteceu. Ela tava chorando e não falou nada. Quando anoiteceu mais, ela amarrou os lençol na janela do banheiro e fugiu junto com a amiga dela. Agora ela tá na casa da cunhada da minha mãe, e eu não vejo mais. Ela só ligou esses dias pra tia, pra dar um recado pra mim. Meus outros irmãos moram com a minha mãe.

Eu tenho duas, mas elas não passaram aqui.

B) $\underline{A}$ ida para casa

Conforme o ECA, a preservação dos vínculos familiares é um dos princípios que devem ser mantidos pelas instituições que desenvolvem programas de abrigo. Ao permitir a ida das crianças para suas casas nos finais de semana, seja semanal ou quinzenalmente, conforme autorização judicial, o abrigo não só estimula a preservação do vínculo familiar, como também mantém as crianças inseridas na sociedade e as prepara para um possível desligamento da instituição. Além disso, tal medida torna a experiência de abrigo menos penosa para a criança. As crianças que têm autorização para ir para casa revelam em seus relatos a satisfação que sentem por manter esse vínculo. 
O que me deixa feliz é ir pra casa.

O que me deixa feliz é ir pra minha casa.

Eu vou pra casa do meu pai, pra casa da minha mãe não.

Vou, numa sexta sim e numa sexta não.

Minha irmã me busca na sexta-feira. Meu pai fica com minha irmã. Ele mora em outra casa, pertinho dela. Antes eu só ia de 15 em 15 dias. Aí a tia (assistente social) mudou, porque eu chorava, eu não queria só ir embora de 15 em 15 dias. Então a tia conversou com o juiz. Aí eu fui embora toda sexta-feira, mas de vez em quando minha irmã não vem me buscar, aí eu não vou. De vez em quando, a minha outra irmã que mora aqui não quer ir embora. Quando eu vou embora, eu só fico na casa do meu pai.

\section{C) As visitas}

Para as crianças que não tem autorização de ir para casa nos finais de semana, a única maneira de manter o vínculo familiar é o recebimento de visitas dos familiares. Ao receberem visitas dos pais, as crianças sentem-se importantes e queridas por eles. Isso fortalece a auto-estima, facilita as interações sociais e a experiência no abrigo. Em seus relatos, as crianças demonstraram como desejam, precisam e valorizam este contato.

Eu vi minha mãe hoje e nos outros dias que ela veio. Antes ela vinha sempre no dia de visita, aí ela parou de visitar porque ela ficou grávida e o juiz proibiu. Ás vezes, eu via meu pai. Só que agora, ele não vem mais por causa que meu vô e minha vó tem problema de coração e ele mora em Minas.

Meus pais vêm me visitá.

Minha vida aqui é boa, meu pai vem visitá eu. Meu pai vem mais, meu pai e minha mãe, mas minha vó não.

Minha mãe mora aqui perto. Ela mora numa casa, ela vem visitar a gente.

Eu vejo meus pais, eles vêm visitar a gente de domingo. Nesse domingo, ele veio visitar a gente. No outro, ele vai visitar meus irmão no outro colégio. Aí, no outro, ele vem visitar a gente de novo. Nesse domingo, meu pai falou que minha mãe tá doente, que ela tá muito, muito, muito doente. Aí ela foi no médico, tomou benzetacil, daí ela piorou. E quando a tia falou pro meu pai que tava na hora das visita ir embora, ele falou assim "pô, tô com saudade dos meus filho, quero ficar aqui com meus filho". Aí eu falei "vai com Deus, dá um beijo na mãe, vou orar pra mãe melhorar". Aí ele falou "Deus te abençoe, tá bom, tchau". Aí ele foi embora.

\section{D) A perda do vínculo}


Algumas das crianças entrevistadas afirmaram não irem para casa, nem receberem visitas dos pais, o que caracteriza o rompimento do vínculo familiar. Em seus relatos, nota-se a tristeza pelo abandono dos pais e o desejo de que estes retomem o contato. Quando há o rompimento, elas sentem-se sozinhas e desamparadas, pois necessitam do amor, da segurança e estabilidade familiar para enfrentar situações estressantes em suas vidas.

Minha mãe não vem mais buscar nois. Antes, ela vinha buscar nois de quinze em quinze dias. E agora, a gente não tá indo mais. A última vez que ela veio, eu tinha 11 (idade atual) e eu não sei porque ela não tá vindo mais.

Você vê a sua mãe?

Não, Só meu padrasto vem me visitar e buscar, às vezes.

Você gosta de ir?

Não. Eu não quero morar com ele, porque ele não é o meu pai. Eu quero morar com a minha avó. Porque na casa dela, eu tenho o que quero. Na casa dela, eu tenho a minha família. .

Eu nunca vou embora... Eu queria ser de ir embora... Ir embora todas as sextas. Podia ser uma sexta sim e uma sexta não.

Por que você não vai embora?

Não sei, acho porque minha mãe não vinha, nem meu pai.

Eles não tão vindo faz um tempão.

Eles ligaram pra você ou você ligou pra eles?

A tia aqui do lar não tem o telefone deles. O dia que ele deu o telefone, ele deu o número errado. A tia disse que já foram no Fórum procurar lá $o$ endereço.

O que me deixa triste é minha mãe não vir mais.

E) A separação da família

O que torna a experiência de abrigo mais difícil para as crianças é a separação da família. Elas revelaram, nas entrevistas, a saudade, a ansiedade e a raiva que sentem por estarem separadas de suas famílias. Referiram gostar do abrigo, mas manifestaram anseio em ir para casa para estar com a família. Demonstraram ansiedade em manter contato e receber notícias. Mostraram-se conscientes de seus comportamentos agressivos por não conseguirem lidar com os sentimentos de frustração e raiva devido à separação.

Não sei porque eu faço essas coisas ruins. Eu fico com raiva quando meu pai não vem visitar a gente, quando todo mundo vai embora e eu fico aqui. No dia de Natal, eu ganhei presente, aí eu comecei a chorar, por causa que todo mundo tava indo embora menos eu. Aí, eu joguei as 
minha coisa no chão e comecei a chora. Aí a tia falou "um dia você vai embora".

Não gosto muito de morar aqui por causa que eu sinto saudade das minhas irmã, da minha mãe, da minha madrinha, do meu tio, de bastante gente.

O que te faz feliz?

Quando eu brinco com a minha irmã, quando eu vou pra casa, quando minha mãe me visita, quando eu vejo meus irmãozinhos.

Tem alguma coisa que te faz ficar triste?

Tem. É quando minha mãe não vem me visitar, aí eu fico perguntando pra tia se ela vai vir. Hoje, ela falou que vinha de manhãzinha. Se ela viesse de manhãzinha, nós ia brincar com o meu irmão no parque.

Queria ter uma vida saudável. Queria ter minha mãe de volta, voltar pra minha casa, morar com a minha mãe, com a minha avó. Queria fazer coisas boas da minha vida, só.

E como você acha que seria a sua vida se sua mãe voltasse?

Seria mais feliz do que é, melhor ficar com a mãe do que ficar sem. Eu queria ficar aqui de semana e no fim de semana ficar com a minha mãe.

Quero ir pra minha casa por causa que eu acho lá legal e eu tô com saudade do meu vô e das minhas madrinhas. Eu quero ver eles, mas o Juiz falou que essa coisa que aconteceu com pai e com minha irmã é muito grave e talvez eu não possa ir embora.

Eu sou feliz, mas às vezes eu sou triste. Um dia, quando era noite, eu fiquei com saudades da minha mãe. Eu chorei, aí a tia me ajudou. Ela falou "faz de conta que eu sou sua mãe". Aí eu continuei um pouco triste, mas só que depois eu me senti melhor. Essa tia vem hoje.

Eu vou conversar com as tias sobre o meu pai, eu vou perguntar se ele vai vir? Se ele ligou dizendo que vai vir? Aí elas vão falar se ele vem ou não vem.

Quando o meu pai vem na visita, eu falo "oh pai, que dia eu vou embora desse colégio?" Eu quero ir embora rápido. Aí, ele fala assim "o seu juiz não resolveu ainda, ele vai pensar no seu caso". Nesse domingo, meu pai falou que minha mãe tá doente, que ela ta muito, muito, muito doente. A,í ela foi no médico, tomou Benzetacil. Daí, ela piorou. E quando a tia falou pro meu pai que tava na hora das visita ir embora, ele falou assim "pô, to com saudade dos meus filho, quero ficar aqui com meus filho". Aí eu falei "vai com Deus, dá um beijo na mãe, vou orar pra mãe melhorar". Aí ele falou "Deus te abençoe, ta bom, tchau". Aí, ele foi embora.

Você pode me contar qual é o desejo dela (da menina do desenho)?

É que a minha família se reúna de novo.

E como vai ser se esse desejo se realizar?

Vai ser melhor pra ela. Ah! Ela vai melhorar na escola, vai melhorar com os amigos. Aposto que ela não vai mais ser brava.

Você acha que essa menina é brava porque está separada da família?

Acho. E ela queria que a mãe dela não tivesse mais raiva do pai dela.

O que você me conta desse lugar que você está pintando? 
É onde eu moro. Ah! É uma casa bonita, legal. Mora ela, os irmãos dela

e a mãe dela.

O que te faz feliz?

Ficar com minha mãe, minhas irmãs, meus amigos.

\subsubsection{Os cuidadores}

Em relação às cuidadoras, as crianças fizeram relatos referentes ao vínculo afetivo, aos castigos e sentimentos de injustiça e aos abusos. As cuidadoras desempenham papel fundamental na adaptação das crianças no abrigo, pois são as pessoas responsáveis por promover o cuidado e o bemestar delas. Estão mais próximas das crianças no dia a dia, portanto, dependendo de sua atuação, a experiência de abrigo pode ter um significado positivo ou negativo.

\section{A) A ausência de vínculo significativo}

O vínculo com as cuidadoras é um dado importante que surge nos relatos das crianças. Estas referem apreciar as instalações, a comida, as atividades, as oportunidades, os passeios, mas em momento algum fazem referências afetivas sobre as pessoas que cuidam delas. Isso evidencia que, mesmo reconhecendo alguns benefícios do cuidado que recebem, as crianças não estabelecem relações significativas com as cuidadoras. Deixam explícito o atendimento de suas necessidades biológicas, sociais e espirituais, mas não fazem menção aos vínculos afetivos com as cuidadoras. Normalmente, na fase escolar, a figura do professor, ou equivalente, costuma ser de suma importância. No caso, as cuidadoras, chamadas de "tias", exercem um papel intermediário entre a figura do professor e a dos pais. Por essa razão, esperava-se que no relato espontâneo das crianças essa figura estivesse mais presente.

Quando questionadas sobre "O que você gosta e o que você não gosta aqui", as crianças não mencionaram as pessoas que zelam por elas.

Gosto do parquinho e daqui de dentro porque aqui eu tenho catequese.

Eu não gosto quando a tia fala que nós não vamos brincar.

Gosto do parquinho. 
Eu gosto de aproveitar minha vida, de brincar, de ganhar coisa e aprender a ler e escrever um monte de coisa. Também gosto daqui porque eu ganho presente.

Minha vida aqui é boa. Tem os passeio, ir pra praia, ir pro shopping, ir pra qualquer lugar. É gostoso. A comida, a sobremesa.

Não tem nenhuma coisa que eu não goste. Eu gosto do lar inteiro. Só.

Eu gosto daqui, porque aqui é legal, tem parquinho pra gente brincar. Tem piano, tem festa de Haloween, tem festa de aniversário, tem festa fora do lar. Nois vai pra pizzaria, pro Mc Donald, pro Shopping. Come pizza, refrigerante. Nois vamos também pro Pão de Açúca. Nois já conheceu o castelo da bruxa. Mas, eu queria ir um pouco embora e voltar.

A gente tem atividade, vai pra escola, a gente tem a nossa vida aqui. Acho que a vida aqui é boa. Acho que não tem nada de ruim. Por exemplo, o pula-pula, o escritório. Tem a oficina, onde fazemos nossas atividades, tem cabeleireiro, tem pipa. A gente faz sabonete, vela, pintura, artesanato, um monte de coisa. Faz chocolate... A gente assiste filme, tem aula de dança. De vez em quando, eu ajudo o tio a cuidar da horta, só isso. Na biblioteca, a gente estuda, faz a lição. Tem a informática, a gente vai lá de vez em quando, mas tem os horários certos. Tem o refeitório e a cozinha onde a gente come. Tem a costura pra quando rasgar alguma roupa ou se a tia for fazer alguma roupa. Tem a lavanderia, onde lavam as nossas roupas. Padaria, onde a maioria das crianças que ficaram aqui nesse mês, aprendeu a fazer queijo, casadinhos, pão, bolo. Tem almoxarifado, que é fechado, não tem nada, põe as camas, esse tipo de sobra. Tem a quadra onde a gente tem atividade de futebol, handebol, basquete, essas atividades esportivas. Tem as mesinhas pra quando a gente recebe alguma visita. Tem parquinho. Tem a nossa casa, que eu não acho nada de ruim, né. Tem as enfermaria, onde têm dentista, enfermeira. A gente tem formação social, psicóloga. Acho que não tem nada de ruim. Eu gosto. Bom, eu gosto de ir a praia, da aula de futebol, também gosto de estudar astronomia. Na escola, nois estuda ciências e tem astronomia.

Eu gosto daqui, porque tem atividade, brincadeira, não tem nada que eu não goste.

As crianças manifestavam sua opinião sobre "as tias" somente quando eram questionadas, pontualmente, a respeito.

As tias são legal porque elas cuidam da gente.

Eu gosto das tias.

As tia é legal, as tia do escritório é legal. Todas as tia da casa é legal.

O que eu mais gosto aqui é das atividades e das tias.

Todas as tias são tudo legal comigo.

São chata, só tem uma tia que é lega. É melhor morar aqui de noite. É mais bom do que de dia porque, de noite, as tias são mais legal. Elas dão doces. Tem uma tia que traz pirulito, chocolate. Todo mundo gosta dela. 
Algumas eu gosto, algumas eu não gosto, porque algumas são chata, deixam nós de castigo. Também, a gente faz bagunça. Outras são legal, mas, na realidade, eu gosto de todas.

Várias eu gosto, elas ouvem a gente, elas deixam a gente ficar mais tempo aqui fora brincando.

Acho que as tias são legais, porque elas brincam. Às vezes, quando a gente bagunça, elas não coloca no relatório, não brigam, porque se colocar no relatório, aí a gente leva ocorrência ou vai parar no escritório.

Algumas eu gosto e algumas eu não gosto. Eu gosto das tias que não me deixa de castigo, não me coloca na cama, não me deixa sem lanchar.

B) Os castigos e o sentimento de injustiça.

Algumas crianças, ao se referirem aos cuidadores, demonstraram sentirem-se injustiçadas. As crianças menores queixaram-se dos cuidadores por delegarem às crianças maiores o poder de dar ordens a elas. Revelaram ter a percepção de que as regras para as crianças grandes são diferentes das regras para as pequenas. Alegaram também que existem crianças que recebem tratamento diferenciado e que algumas acusações são injustas. $\mathrm{Na}$ fase escolar as crianças estão mais atentas a valores morais, tendem a agir em conformidade com as normas e estabelecem regras rígidas. Por isso, crêem que todos devem obedecer as mesmas regras e receber as mesmas punições. Quando isso não ocorre, sentem-se frustradas e acreditam serem vítimas de um tratamento injusto. Kohlberg apud Hoffman (1978)

As tia do escritório briga com nós, porque nós faz bagunça. Às vezes, nós briga e a tia briga com nós. Ela leva nós na sala e briga com nós, mas não briga de bater. Ela conversa. Às vezes eu acho chato conversar com as tia do escritório (equipe técnica). As tias da casa (educadoras) só brigam às vezes. Elas colocam nós pra dormi sem o lanche da noite. Aí eu me sinto mal porque a tia coloca pra dormi sem ver TV. Fico ruim, fico com raiva, aí eu brigo. Às vezes, quando a tia fala pra limpá a casa, eu fico com raiva, porque elas manda só as pequena, $e$ as grande? Quando as pequena não quer entrar pra casa, a tia pede ajuda pras meninas grande.

Eu não gosto das tias do escritório, eu odeio elas! Elas são muito ruins. Sabe por que? Assim oh! Tem uma menina aqui do lar que não precisa de nada, aí a tia dá muitas coisa pra ela. A menina sai pra qualquer lugar e nós fica aqui. As meninas fica muito revoltada porque vai no cabeleireiro, vai jantar fora, almoçar e nós não. É por isso que nós não gosta dela, porque ela inventa que o pai dela tá doente, que a mãe dela tá internada, aí as tia ajuda ela.

Têm algumas tias que eu não gosto. Esses dias aí, teve uns meninos que pularam ali atrás no fundão, quebraram a porta da manutenção, entraram lá dentro, roubaram algumas coisas, pularam o portão da 
escola, ficaram jogando futebol na quadra, foram lá pra trás da igreja, zoaram dentro da igreja. Aí, depois, teve uma tia que jurou que me viu lá e eu não tava. Ela foi a única que me viu. E tinham mais três tias que foram ver quem era que tava pulando e só ela me viu, ninguém me viu e nem o meninos que pulou me viu também. Não sei, só se ela se enganou, se ela queria me ferrar. Aí eu não sei. Que eu não tava lá, isso eu sei. $E$ isso me deixa triste, quando a gente leva bronca sendo que a gente nem fez essas coisas. Por exemplo, eu quase fui junto com eles pra delegacia pra fazer o boletim de ocorrência, porque aquela tia jurava que me viu, mas eu acabei não indo.

As tias manda nois para fila e se nois não quer ir, ele (menino mais velho) vai e fala "vai muleque, se não você vai levar um soco" e fica batendo nos outros. Aí eu falo com a tia, a tia nem encana com ele. Diz "pode bater". Num outro dia, eu tava ali e a tia pediu pra eu ir lá no quartinho lá dentro. Daí a tia brigou com nois dois. Aqui é assim oh, se xingou a tia, aí leva uma ocorrência grave ou só leva ocorrência normal. Aí as tia do escritório chamam pra falar com a gente, pra levar bronca. Aí fica no trabalho educativo.

\section{C) Abuso}

O abuso aparece em dois relatos. As crianças relataram agressões físicas e formas inadequadas de repreensão verbal, caracterizando abuso psicológico. O ECA determina no art. 18 que é dever de todos velar pela dignidade da criança e do adolescente, pondo-os a salvo de qualquer tratamento desumano, violento, aterrorizante, vexatório ou constrangedor. Ao destinar este tratamento às crianças, estes cuidadores desrespeitam o ECA e a criança, criam um ambiente desfavorável ao desenvolvimento saudável, distorcem a função do abrigo, tornando este uma experiência negativa para as crianças. Brasil (1990)

Gosto de todas, menos de uma tia. Porque quando eu entrei aqui, ela me beliscava e eu ria, nem doía.

São chata. Ah! Tem uma que falou assim pra mim "eu nem quero olhar pra sua cara, nem falar com você". Só porque ela tava me chamando e eu não fui, é isso. Tem uma tia que até joga nós na parede. Ela fala assim: "até pode falar pra tia do escritório que eu tô morrendo de medo". Um dia ela pegou uma menina e apertou a mão dela e jogou ela na parede. A tia sabe. Todas as tias do escritório sabem o que essa tia faz, porque as menina falam. Aí as tias do escritório falam que vai despedi essa tia daí, mas nem despede. 
Os relatos das crianças referentes ao significado da experiência de abrigo mostraram ambivalência de sentimentos em relação à instituição. Elas não reconhecem o abrigo como sua casa, contudo percebem que ele atende melhor as necessidades materiais do que suas famílias. Elas sentem que, no abrigo, são bem cuidadas e estão protegidas, têm melhores oportunidades de aprendizagem e maior acesso ao lazer. Gostam da instituição, mas desejam que essa situação seja transitória e que possam retornar para casa. Além disso, ao mesmo tempo em que os limites impostos pelas rotinas e normas permitem que as crianças sintam-se cuidadas e protegidas, eles causam descontentamento devido às repreensões e falta de liberdade.

Os desenhos e os relatos das crianças foram instrumentos eficazes para identificar a negação do reconhecimento do abrigo como sendo casa. Quando as crianças eram convidadas a desenharem a casa onde moravam, desenhavam a casa de sua família. Nos relatos, todas as crianças se referiram ao abrigo como sendo um colégio. Esses dados demonstraram que, para elas, casa e família simbolizam a mesma coisa.

Existem duas maneiras de se definir símbolo em psicologia, proveniente de duas formas de se estudar e enfocar a simbolização. São elas: cognitiva, para a qual símbolo é a capacidade de representar algo em sua ausência; e psicodinâmica, para a qual os símbolos são produzidos afetivamente e sinalizam os conteúdos da vida psíquica. Enquanto as teorias cognitivistas assumiram o símbolo como representação, as psicodinâmicas o assumiram como substituição. Rabinovich (1997)

A casa pode ser considerada tanto um símbolo cognitivo, quando relacionado a maternagem (isto é, como representação da relação mãecriança durante sua vida uterina), quanto um símbolo psicodinâmico, porque substitui o útero em suas funções de proteção, sendo uma extensão e um reflexo da maternagem. Rabinovich (1997)

Um estudo realizado sobre o significado de família para crianças de duas culturas diferentes, apreendeu que elas simbolizam a família como um lugar, significando meio ambiente (um lugar de cuidados, um lugar para 
crescer e um lugar de valor). O estudo revela que, em ambas as culturas, as crianças esperam obter da família abrigo e segurança, mas se percebem vulneráveis e frágeis, pois vivem relações permeadas de atitudes rudes e, às vezes, violentas. Essa vulnerabilidade faz com que as crianças valorizem as interações familiares e criem elos afetivos, principalmente com os pais. Ângelo apud Ribeiro (1999)

Considerando que a criança simboliza a família como um lugar de cuidados, de valor e um lugar para crescer, onde busca abrigo e segurança; e, partindo do pressuposto que ela simboliza a casa como a relação mãecriança na vida uterina e, ainda, substitui a casa pelo útero, em sua função de proteção, pode-se concluir que o sentimento de proteção se consolida pelos vínculos afetivos. Isso pode explicar porque as crianças não simbolizam o abrigo como sua casa, mas como um local onde algumas necessidades são melhores atendidas. Ou seja, para as crianças, a casa é um lugar de afeto maternal e o abrigo um lugar de formação, orientação e educação.

Um estudo realizado com brasileiros institucionalizados resilientes demonstrou que as instituições "nortearam, modelaram e/ou ajudaram na formação de comportamentos, através do que se denominou "paternagem", ou seja, o exercício da função educativa de responsabilizar, dirigir e mostrar o caminho". Alvarez, Moraes, Rabinovich (1998)

Nesse sentido, pressupõe-se que, para as crianças, a casa significa a figura materna e o abrigo a figura paterna. Este vazio afetivo parece ser parcialmente preenchido nas relações com o grupo de amigos. Nos relatos, as crianças revelaram a satisfação que sentiam por ter amigos e como as amizades facilitaram sua adaptação no abrigo. Ao fazerem parte de um grupo, elas sentiam que não estavam sozinhas, que podiam contar com alguém, que eram queridas e que tinham valor, quesitos que normalmente se busca na relação materna.

As crianças "precisam de pessoas em torno delas em quem possam confiar simplesmente em virtude do fato de que são seres humanos dignos 
de confiança, com uma capacidade comum para a amizade humana". Winnicott (1971)

Devido à separação da família e à necessidade que elas têm de sentirem-se rodeadas de pessoas em quem possam confiar, as crianças institucionalizadas substituem as relações familiares pelas relações com os amigos.

Contudo, ao mesmo tempo em que essas relações suprem necessidades afetivas, elas também são fonte de conflitos e más influências. Isso ocorre devido à busca de aprovação dos companheiros. Para permanecer no grupo, a criança aceita suas regras e concorda em fazer as mesmas coisas. Porém, muitas vezes esses comportamentos são considerados socialmente inadequados. A participação das crianças em ações anti-sociais produz sentimento de culpa e arrependimento.

Em um estudo realizado sobre resiliência com brasileiros institucionalizados, as autoras levantam a hipótese "de que a vida comunitária pode ocasionar um apego excessivo a um grupo de companheiros, com uma dificuldade de diferenciação deste grupo, com conseqüências como delinqüência por aderência emocional ao grupo". Alvarez, Moraes, Rabinovich (1998)

Embora a delinqüência infanto-juvenil seja um tema complexo, sabese que há algo em comum entre os infratores, a ausência de figuras que desempenhem de forma satisfatória os papéis de pai e mãe. Assim, a delinqüência pode ser um pedido de socorro, para que a criança seja controlada por pessoas fortes, carinhosas e confiantes. Quando uma criança rouba, está procurando pela mãe e pelo pai. Ela tenta preencher o vazio da ausência materna e busca uma autoridade paterna que imponha limites em seu comportamento impulsivo. Winnicott (1971)

As crianças institucionalizadas cometem atos ilícitos para preencher seu vazio em dois aspectos: em relação à busca da mãe e em relação à permanência no grupo. Cabe portanto ao abrigo, a função de pai que corrige 
e orienta. Como ele vem desempenhando satisfatoriamente esse papel, as crianças manifestaram arrependimento e culpa.

Os conflitos no grupo de amigos ocorrem como em qualquer relação humana. $\mathrm{O}$ que os diferencia é a maneira como as crianças os enfrentam. Utilizam-se geralmente, de agressões verbais e físicas para resolvê-los por não conseguirem encontrar outras formas de enfrentamento.

Em 1999, o Centro de Referência às Vítimas de Violência do Instituto Sedes Sapietiae (CNRVV) realizou, em parceria com outras instituições, um estudo em um Centro da Juventude, com crianças vítimas de violência para conhecer o perfil e o modo como se dão as relações sociais nos diferentes níveis. $\mathrm{O}$ estudo mostrou que, apesar de encontrarem indícios de que essas crianças se reconheciam no outro, tal possibilidade não se configurava em um fator de união. A análise dos dados indicou relações permeadas de competição e disputa, invasão e desrespeito, roubo, agressividade e destruição, além de sentimento de inveja, cobiça, ciúmes, dissimulação e traição. Vecina, Cais, et al (2002)

Os dados do referido estudo correspondem a algumas falas das crianças deste. Ao relatarem seu cotidiano no abrigo, algumas crianças revelaram que suas relações, muitas vezes, são conflituosas, desrespeitosas e agressivas.

E, por que é assim? Porque elas têm história de violência familiar. Não é possível traçar um único perfil dos vitimizadores, mas é possível traçar um perfil das interações familiares, nos lares, onde ocorre a violência, a existência de uma disfunção que evidencia a desigualdade. Sousa e Silva (2002)

"Essa desigualdade nada mais é do que a assimetria do poder - a submissão do mais fraco pelo mais forte que se traduz em maus tratos físicos, em abuso sexual contra meninas e meninos, negligência e abandono. Crianças e adolescentes, que precisam de cuidados por se 
encontrarem em fase especial do desenvolvimento, são surrados, queimados, ameaçados, menosprezados, abusados sexualmente entre outras barbáries". Sousa e Silva (2002)

"Diante da desigualdade de poder, o grande perdedor é a sociedade. Os reflexos podem ser notados tanto no presente como no futuro. As vítimas acabam assimilando valores desfigurados de respeito humano. A vulnerabilidade e a franqueza temporárias da criança, enquanto vítima, podem dar lugar à formação de pessoas que exerçam o papel de agressoras dentro e fora do contexto familiar, mediante mecanismos de introjeção e identificação com o que a vitimiza. É a violência dentro da família gerando a violência social”. Sousa e Silva (2002)

A identificação com valores familiares leva as crianças a resolvem conflitos no grupo, utilizando-se de formas agressivas de enfrentamento. Somando-se a isso, a separação da família torna a experiência de abrigo mais difícil e dolorosa. Para elas, a família é o centro do seu afeto e de suas preocupações. O processo de análise dos dados possibilitou perceber que a separação causa intenso abalo emocional e muita dificuldade para lidar com a situação.

O que proporciona certo conforto às crianças é a possibilidade de manterem algum vínculo afetivo com os pais através dos retornos temporários para casa e das visitas recebidas. Mas, não são todas que podem usufruir desse benefício. Algumas têm antecedentes de total rompimento com a família. Por ordem judicial, não têm permissão para ir para casa, nem os pais são autorizados a visitá-las. Para estas, a dor do abandono é intensa.

"A dor da rejeição, do abandono e da negligência gera frustrações, insatisfação crônica das necessidades básicas e baixa auto-estima. Para um grande número de crianças, a carência do amor e da "nutrição afetiva" cria condições propícias para o nascimento do ódio e da revolta que desemboca em condutas violentas e em delinqüência”. Maldonado (1998) 
Além de enfrentarem a separação dos pais, as crianças têm de enfrentar a separação dos irmãos. Tendo em vista que a criança em situação de abrigo, via de regra, tem antecedentes dramáticos de pobreza, desagregação social, desrespeito aos direitos sociais, situação de abandono e ruptura de vínculos com a família e a comunidade, o Conselho Municipal dos Direitos da Criança e do Adolescente - SP publicou a resolução no 53/CMDCA/1999 para regulamentar a lei estátutaria quanto ao não desmembramento do grupo de irmãos. São Paulo (1999) ${ }^{2}$

Os irmãos são importantes para o desenvolvimento das crianças. Embora elas não dependam destes para atender suas necessidades físicas, estes oferecem estímulo social, competição e são parte íntima de sua vida cotidiana. Além disso, a separação leva ao rompimento de mais um vínculo afetivo. Briggs (1986)

Essa necessidade manter vínculos afetivos, leva à idealização da família. Mesmo sendo vítimas de violência intra-familiar, as crianças não se referiam à sua família de forma negativa, ao contrário, afirmavam desejar voltar para casa e diziam que o que as deixava feliz era ir para casa e estar com sua família.

Em um estudo sobre "a compreensão de família sob a ótica de pais e filhos envolvidos na violência doméstica contra crianças e adolescentes", observou-se que "a institucionalização, de alguma forma, contribui para preservar uma imagem de pais que só existe na esfera do ideal, impedindo que essas crianças e adolescentes enfrentem a realidade em que vivem". Martins (2005)

É possível que as crianças idealizem a figura dos pais para evitar o sofrimento do abandono e para nutrir um sentimento de esperança de que alguém os ama e que sua situação de vida poderá ser modificada. De Antoni apud Martins (2005)

\footnotetext{
${ }^{2}$ Dados encontrados no site:

http://portal.prefeitura.sp.gov.br/cidadania/conselhosecoordenadorias/cmdca/legislacao/001 4. (31/05/06).
} 
Essa necessidade de idealizar os pais demonstra que, embora separadas deles, seu principal vínculo afetivo ainda é com a família, principalmente com a mãe. A figura materna não é substituída pela cuidadora. Os relatos das crianças mostraram que as crianças reconhecem o cuidado prestado, mas não estabelecem vínculos significativos com quem cuida.

A dificuldade das crianças em estabelecer vínculo afetivo pode estar relacionada: às suas frustrações em sua trajetória de vida, à rotatividade de funcionários e à capacitação dos profissionais para lidar com essas crianças.

O primeiro caso pode ocorrer por seqüela da violência familiar. Diversos pesquisadores, citados por Duarte e Arboleda (1997), apontam reações de evitação e resistência ao apego como conseqüências da violência sofrida por crianças.

No segundo caso, a rotatividade dificulta a formação de vínculos, pois a criança com histórico de privações afetivas necessita de uma atenção mais personalizada. "É a natureza permanente do lar que o torna valioso, mais do que o fato do trabalho ser realizado com inteligência”. Winnicott (1971)

O terceiro caso ficou evidente em alguns relatos das crianças quando se referiram a abusos praticados por alguns cuidadores. Contudo, é importante ressaltar que isso parece ocorrer de forma isolada. Não diz respeito a todos os cuidadores. Mas sua ocorrência impede a criança de superar traumas, cria um ambiente inseguro. E ainda, distorce a função do abrigo que é, primordialmente, de proteção.

"Dentre as necessidades primordiais de crianças com um passado de ruptura e sofrimento, está a possibilidade de encontrarem ambiente adequado, atmosfera que as ajude a encontrar segurança e bem-estar, um quadro não somente acolhedor, mas também estável". Nogueira, Costa (2005) 


\subsection{A auto-imagem}

A sistematização dos dados permitiu visualizar que a auto-imagem das crianças estava associada à sua trajetória de vida, à visão do amigo, à imagem corporal e ao autoconceito.

\subsubsection{A trajetória de vida}

As crianças faziam relatos referentes à sua condição de miséria, a perda da figura materna, a fatos que configuram negligência dos genitores e antecedentes de violência física e sexual. Esses elementos são experiências que interferem na construção da auto-imagem da criança. A criança em idade escolar percebe que sua experiência e sua condição social retratam o que ela é, mas não consegue estabelecer relação direta entre sua autoimagem e sua trajetória de vida. Mas, ao contar sua história, expõe experiências significativas que revelam, de forma sutil, seu perfil.

\section{A) A miséria}

Em outros relatos, a miséria é a justificativa dada pelas crianças para sua colocação em abrigo. Ao contarem o motivo que as levou ao abrigo, revelam fatos que demonstram uma situação de desagregação familiar e extrema pobreza. Uma viveu em um albergue e a outra na rua, ambas acompanhadas pela família. Levando-se em consideração que todas as experiências que vivenciamos marcam o nosso desenvolvimento e que a criança escolar percebe que seus antecedentes e sua condição social influenciam a maneira como é vista e, ainda, dada à importância que o olhar do outro adquire para a sua auto-imagem nesta fase do desenvolvimento, pode-se afirmar que estas situações contribuem para uma imagem negativa de si próprio. No entanto, ao relatarem sua trajetória, as crianças não fazem esta conexão.

Vim morar aqui porque nós tava num albergue. Minha mãe, meu pai e meu irmãos. Tenho quatro irmãos, mas tenho outro que ta lá no hospital, no outro canto. 
Vim pra cá porque minha mãe tava doente e o meu pai não tava trabalhando também e minha irmã tava grávida. Aí, o Fórum me tirou da minha casa e colocou aqui. Aí, fui pra casa de passagem e vim pra cá. Eu vim primeiro e depois a minha irmã mais nova. Antes de acontecer isso, eu morava na rua. Eu, minha irmã mais velha, o meu pai e a minha mãe. A N. nem tinha nascido ainda. Eu morava na rua e sempre a polícia passava. Aí, teve um dia que uma mulher tava bisoiando a gente, eu e minha irmã mais velha. Nois sempre ia na casa dela pedi comida. Aí, ela gostou da gente muito e levou a gente pra casa dela. Ela pegou os documento meu e da minha irmã com a minha mãe e criou a gente. Depois ela não agüentou mais a gente e mandou nois pra rua de novo. Um dia, minha mãe tava no banquinho, bêbada. Aí, esse negócio assim... do lar... passou lá na rua, pegou eu e a minha irmã e levou pra um colégio interno e, de lá, levou nois pra casa de passagem e depois pra cá.

E seus pais continuaram morando na rua?

$E$ É e depois, minha irmã, a mais velha, começou a trabalhar e minha mãe, meu pai e ela moravam numa pensão. E aí, minha mãe começou a trabalhar numa empresa de fazer lençóis. Aí, o Fórum deixou nois ir embora toda sexta. Mas, minha mãe foi despedida do emprego. Aí, o Fórum falou pra nois não ir mais. Aí, eu num fui mais embora. Depois, minha mãe morreu. Aí, meu pai, agora, tá trabalhando.

\section{B) A ausência Materna}

A morte da mãe como causa para a institucionalização surge em algumas falas. Embora as crianças não associem a perda à auto-imagem fica evidente a dor causada pela ausência da mãe. A figura materna é normalmente a principal cuidadora e, como tal, possui grande influência na construção da auto-imagem da criança. Quando esta criança perde a mãe, e outra pessoa não desempenha este papel, a criança perde esta referência.

Quando eu nasci meu pai voltou para África. Ele só me deu um beijo e depois foi. Minha mãe morreu de arma. Usaram ela. Meu padastro usou ela (a mãe). Ele matou ela na cama, no dia do aniversário dela. Ele colocou a arma na boca, depois atirou no céu da boca. Eu tinha nove anos. Aí minha vó me levou numa casa de passagem. Eu falei que não queria ficar lá porque as crianças ficavam fumando cigarro. Aí, depois eu saí de lá e a moça me levou pra esse colégio (o abrigo). Aí, eu fui lá pra minha unidade. Daí, eu fiquei lá e fiz bastante amiga. Minha vó falou que podia ficar com a gente, mas só que a gente faz muita bagunça. Não ter mãe, me deixa triste.

Minha mãe tava doente. Ela fumava, bebia, ela tinha problema no coração. Aí ela faleceu. É assim... Eu morava com minha mãe, meu pai e minhas irmãs. Aí minha mãe tava doente, ela ia pro médico, pro hospital. Aí, ela me trouxe pra cá porque faz tempo que ela não tinha mais como me criar. Um dia, eu fui na casa da minha mãe e ela falou assim "se eu morrer você ainda vai ter sua irmã". Aí, eu comecei a chorar. Aí, eu falei "não, você não vai morrer". Aí, eu falei pra tia (cuidadora no abrigo) e ela falou que era tudo mentira. E aí, minha mãe morreu. (Seus olhos se encheram de lágrimas). 
Eu vim morar aqui porque minha mãe morreu e meu pai não podia ficar com a gente, porque ele ta trabalhando e nois era criança.

C) A negligência

Houve crianças que externaram, de forma implícita, a negligência dos pais como motivo para a institucionalização. As crianças relataram a impossibilidade da família em cuidar delas devido ao trabalho. No entanto, duas delas não recebiam visitas dos pais e as outras duas, raramente recebiam. Essa tentativa de justificar a ausência dos pais reflete a resistência da criança em aceitar a indiferença destes. As justificativas minimizam seu sofrimento.A família desempenha um papel importante no desenvolvimento de uma auto-imagem positiva nas crianças, pois é através do vínculo afetivo que estabelecem com a família que as crianças adquirem a capacidade de confiar no outro e conseqüentemente em si própria. É essa confiança em si que as faz tentar novas experiências e obter sucesso. Quando há um rompimento deste vínculo caracterizado por negligência e abandono, as crianças apresentam dificuldades em ter sentimentos positivos com relação ao mundo e a si. Bowby (1990)

Vim morar aqui por causa que minha mãe tinha um trabalho assim: ela ia um dia, mas só voltava no outro dia. Não ficava ninguém em casa com a gente e era a minha irmã mais velha que fazia a janta pra nós. Aí, um dia ela deixou a minha irmã mais velha em casa porque ela já sabe cuidar de casa e levou eu e a minha outra irmã pro trabalho dela, de manhãzinha. Ela vai de manhã e só volta depois de amanhã. Aí, descobriram que a minha mãe ia trabalhar e só voltava depois de amanhã. Aí, eles falaram com a minha mãe e a minha mãe aceitou deixar a gente aqui. Só que meu pai não queria que nós ficasse aqui.

Eu vim pra cá porque minha tia não podia cuidar de mim e minha avó, minha mãe, todo mundo trabalhava.

Vim aqui porque minha mãe tinha que arranjar um trabalho. Aí ela conseguiu, mas era só de noite, aí ela deixava nós na casa sozinha e aí nós falou pra ela deixa a gente na casa de alguma tia, então ela pediu pras irmã dela, nossa tia, cuidar da gente, mas aí colocou nós aqui.

Não sei explicar direito... minha mãe tinha... queria me deixar na porta do Fórum.

D) $\underline{A \text { violência }}$

A violência doméstica foi outra razão apontada por algumas crianças para sua institucionalização. Em dois casos, as crianças foram vítimas de maus-tratos e, no outro caso, a irmã da criança foi abusada sexualmente 
pelo pai.A violência acarreta sérias implicações à auto-imagem da criança, pois esta mede seu valor pela forma com que é tratada. Ela associa a truculência da punição com a gravidade da falta cometida. Isso faz com que se sinta culpada e merecedora da agressão, levando-a a um sentimento de inferioridade e a um autoconceito negativo. Briggs (1986)

Eu vim ai porque eu bagunçava. Não, eu não bagunçava. É porque meu pai me batia. A minha mãe só batia às vezes, quando eu bagunçava. Quando eu vim morar aqui, veio eu e minhas irmãs.

Vim morar aqui porque aconteceu um negócio com a minha mãe, com meu pai e com a minha irmã. Por causa que, quando aconteceu o acidente, lá dentro da minha casa, o meu pai e a minha irmã tava lá na cama. Aí, a minha outra irmã viu eles fazendo o negócio lá. Aí, a minha irmã que tava na cama com o meu pai fugiu de casa e ligou pra polícia. Aí, ela falou pro homem o que o meu pai fez e aí ele foi preso. Aí, primeiro eu e minhas duas irmã foi para outro colégio, depois pra outro e depois foi pra este.

Vim pra aqui porque o juiz mandou. Problema de família. Bom, é assim né, eu morava na minha casa e de vez em quando meu pai maltratava a gente. Aí, o meu pai saiu de casa e foi morar numa outra casa, aí a gente se mudou para uma outra casa que ficava perto da nossa escola, porque a gente estudava longe. Aí, o juiz mandou a gente pro lar, porque o meu pai ameaçava a gente de morte, porque ele queria que a gente voltasse pro lugar onde a gente nasceu e a qente não queria voltar agora. A gente queria voltar quando a gente crescesse. A gente ia com a nossa mãe.

\section{E) O tempo de institucionalização}

Conforme estabelece o ECA, o tempo de permanência da criança no abrigo não deve ultrapassar a dois anos, mas, em geral, as crianças entrevistadas já haviam passado esse limite de tempo. Esse excedente levou algumas delas a perderem a noção do tempo passado. Essa desorientação também reflete em sua auto-imagem à medida que passa a ignorar sua idade. Isso dificulta a identificação com seus pares. É comum os adultos fazerem referências separando crianças por idade, fazendo distinção entre maiores e menores. A criança que não tem noção de sua idade perde esse parâmetro de comparação. Brasil (1990)

Eu moro aqui desde que a minha mãe morreu. Eu tinha nove anos.

Eu moro aqui desde 2003.

Moro há sete anos.

Desde 2002. Quando eu entrei aqui no lar eu tinha 6 anos. 
Desde 2003, por aí. Eu tinha oito anos quando entrei, agora eu tenho nove e daqui a pouco eu faço dez.

Moro aqui desde 98.

Desde 2004, sei lá, acho que fez um ano em novembro.

Aqui eu entrei em 2003, mas minhas duas irmãs já tava aqui.

Moro há oito anos.

Não lembro. Eu só sei da minha irmã mais velha, ela morou aqui seis anos, mas ela fugiu. Eu moro aqui desde pequenininha.

Num sei..., humm, Três anos.

Eu não sei não. Hoje eu to com dez anos. Não sei mais, não lembro.

Faz tempo, eu não lembro quando. Acho que eu tinha sete..., eu não lembro.

\subsubsection{A visão do amigo}

Com relação à visão do amigo, as crianças fazem referência a opiniões positivas e negativas e a como estas influenciam sua imagem corporal. As crianças que se sentiam apreciadas pelo grupo de amigos faziam questão de relatar esse apreço, mesmo quando a pergunta formulada não estava relacionada à visão do outro. Os comentários revelavam o contentamento por serem aceitas e a necessidade de compartilhar isso. Já as crianças, cujos amigos atribuíram alguma opinião negativa, demonstraram em suas falas o quanto sua auto-imagem estava suscetível a esta visão. Essa influência ocorre porque, na idade escolar, as relações sociais fora do ambiente familiar ganham um significado maior. Além disso, elas tornam-se mais conscientes das pressões sociais que estabelecem padrões de comportamento uniformes. Por isso, as crianças tornam-se ansiosas para corresponder às expectativas e serem aceitas pelo grupo. Quando, por algum motivo não conseguem, sentem-se rejeitadas, desvalorizadas e, em alguns casos, acabam por incorporar essas opiniões.

Como você se vê?

Ah! Eu não sei. Os outros que pode dizer.

Como você acha que as pessoas te vêem?

Ah! Acho que é bonita, que sou muito alegre, muito amigável, muito fofoqueira.

Uns dizem que eu sou muito bonita.

Você se acha uma menina bonita ou feia?

Feia, por causa que as meninas fica me xingando de um monte de coisa feia, de palavrão. 
Eu gosto do meu reflexo, mas tem gente branca que fica tirando a gente de neguinha sarava e os menino ficam me xingando de macumba.

O que você acha que seus amigos acham de você?

Eles me chamam de feia, eles me xingam de macumba e só. Eu fico quieta e triste, porque é mentira, eu não faço macumba.

Me acho bonita, um pouco. É por causa que eu não gosto da minha sobrancelha, por causa que as menina fica chamando a gente de lobisomem, me chama de taturana, e eu fico triste e falo: é você.

O que te deixa triste?

Tem muitas tia, mexer comigo, me zoar, me xingar de E.T., de um monte de coisa, porque eu não sou.

\subsubsection{A imagem Corporal}

Em relação à imagem corporal, as crianças apresentaram tanto imagens positivas quanto negativas. A principal parte do corpo citada pelas crianças foi a cabeça e as estruturas que a compõe, o que leva a crer que esta seja a parte mais importante da auto-imagem percebida pelas crianças. $\mathrm{Na}$ fase escolar, as crianças são fortemente influenciadas por pessoas significativas, pelas normas culturais e por modismos. Isso ficou evidente nos discursos. Além disso, as crianças associavam sua imagem corporal à sensação de bem/mal-estar.

\footnotetext{
Fale-me sobre como você se vê?

Bonita.

O que te faz bonita?

Ficar feliz.

Você gosta do seu reflexo no espelho?

Depende, tem dia que eu to feliz, tem dia que eu acordo com mau humor. Quando as tias acordam a gente bem cedo pra ir pra escola e eu to com aquela cara de sono querendo dormir, querendo mandar a tia deixar a gente ficar só mais meia hora, mais não dá, tem que ir lá fazer uma coisa que a gente não gosta, ir lá e jogar água no rosto pra gente acorda direito. É mor chatice, tá dormindo numa boa, aí acende a luz e acorda a gente pra se arrumar. Na maioria, eu não gosto porque eu tô com sono e tem que acordar cedo, só de final de semana que a gente fica dormindo até umas horas.
}

Algumas crianças, embora tivessem um julgamento sobre sua imagem não sabiam especificar o que exatamente as fazia bonitas ou porque se sentiam feias.

Me acho bonita.

O que te faz bonita?

Tudo.

Quando você se olha no espelho, você gosta ou não do que vê? 
Gosto.

Do que você gosta?

Ah! Gosto de mim.

Me acho bonito. Eu sou bonito.

Me acho mais ou menos... Ah! Eu me acho feia.

O que você acha feio?

Não sei.

Tem algo que você acha bonito em você?

Tem, o cabelo.

Houve crianças que relacionavam a imagem corporal positiva a relações afetivas. Uma delas sentia-se satisfeita com sua imagem devido ao fato de ter um sinal igual ao do pai. Uma outra, manifestava satisfação quando se arrumava para ir a casa de sua família.

Quando você se olha no espelho, como você se vê?

Meu olho tem uma manchinha igual à do meu pai.

Você gosta ou não do que você vê no espelho?

Gosto.

Você se acha uma menina bonita ou feia?

Bonita.

O que você acha bonito em você?

Eu acho as mãos, os pés, o corpo inteiro.

Gosto, eu gosto do meu rosto. Eu não me acho, eu sou bonito.

O que te faz bonito?

Tudo, eu me acho bonito quando eu saio pra ir embora.

Outras crianças demonstravam a influência cultural da sociedade em sua imagem corporal.

Gosto do meu reflexo. Eu gosto mais da minha risada! Eu não gosto do meu cabelo, eu odeio ele. (Seu cabelo é crespo).

Me acho bonita. Porque ser diferente é bom. (Aponta para as sardas em seu rosto).

Se eu me acho bonita ou feia? Me acho feia. Porque eu não gosto... a única coisa que me estraga é o meu cabelo. Eu me acho bonita, mas a coisa que me estraga eu é o meu cabelo. (Cabelo crespo)

Como você se vê?

Cheia de bolinha... Porque eu fico me coçando. Sai um monte de bolinha em mim porque eu tenho alergia de alguma coisa.

Sou $60 \%$ bonito e $40 \%$ feio, pra não exagerar, né. Melhor que zero por cento pros dois, né. O que eu acho de bonito em mim é meu cabelo quando era grande. Meu cabelo assim é ridículo, quando cortou, era mais curto que isso.

Por que cortou?

Ah! Sei lá. As tias ficaram falando pra mim cortar que era melhor. Vieram cortar porque aqui é fácil de pegar piolho, porque meu cabelo era grande. Mas não era tão grande assim. Mas era bem maior que 
isso. Aí, elas falavam que a maioria aqui tem piolho e não sabe cuidar. Aí, passa pro outro. Assim... não fui obrigado, mas achei melhor cortar porque, se depois pega piolho, fica ruim pra mim.

Me acho bonito. Gosto do meu rosto, do meu cabelo, dos olhos, da boca, do nariz.

O que te faz bonito?

Meu estilo de boyzinho, andar todo arrumado, andar de corrente, de relógio. Eu ando assim quando eu vou sair pros passeio.

\subsubsection{0 autoconceito}

Referente ao autoconceito, é possível visualizar que as crianças o relacionam à socialização, ao "senso de indústria", Erikson (1971), à incorporação de valores sociais e ao bem-estar. Esses elementos permitem a constatação da importância das relações sociais, do brincar, da realização de tarefas, do sentimento de aceitação e de bem-estar na construção da auto-imagem das crianças.

\section{A) Relacionado à socialização}

Nestes relatos, é possível apreender como a socialização contribui para a formação de um autoconceito positivo. As crianças referem que se acham boas, felizes, legais e divertidas porque brincam e tem amigos. Para a criança em idade escolar, o grupo de amigos é um dos mais importantes agentes de socialização. É através dos grupos e das brincadeiras que a criança aprende a se relacionar com o mundo e a seguir regras sociais. Entretanto, pois para fazer parte dos grupos, ela precisa adotar comportamentos uniformes ao do grupo. $\mathrm{O}$ fato de ter amigos e pertencer a um grupo a faz se sentir aceita, levando-a a desenvolver uma auto-imagem positiva.

Sou uma menina boa. Um dia, foi maior engraçado aqui perto do lixo. Eu e as minhas irmãs somos engraçadas. A vó jogou um monte de copinho fora, bonitinho. Aí nós pegamos uma sacola cheinha de copo e mais uma, né. Aí, a tia olhou e me viu. Aí, eu saí correndo nas escadas e quase tomei um escorregão. Aí, a minha irmã saiu a mil. Aí, eu falei "por sorte que a tia não viu nós, só eu. Aí, a tia viu nós lá no fundo da casa, por causa que a $N$. tava vindo muito correndo do parque. Aí, aí quando a tia tava levando o negócio pro lixo, nós guardamos um pouco e achamos uma fita, aquelas fitas de vídeo, só que não era uma fita boa. 
Sou feliz.

E o que te faz feliz?

Quando alguém brinca e conversa comigo.

Sou muito divertida, tenho muitos amigos, também provoco muitas pessoas, sou malcriada. Ah! Num sei, muitas coisas mais. Ah! Eu falo demais, também. Gosto de lutas. Adoro muitas atividades de esporte. $O$ que mais..., zôo muito com as pessoas, adoro aloprar. Odeio fazer a lição, sempre chego atrasada na escola. Ah! Acho que só.

Sou uma menina feliz.

E o que te faz feliz?

Tudo. Quando minha família vem, quando eu tô brincando, fazendo qualquer coisa boa.

Não sei... eu sou bravo quando alguém é bravo comigo, quando alguém xinga eu, xinga minha mãe.

Você se acha um menino legal ou chato?

Um menino legal. Eu brinco, eu gosto de brincar com os meninos.

Sou boa. Legal, porque eu tenho amigas.

B) Relacionado aos valores sociais

No que se refere à incorporação de padrões sociais, os dados demonstram que as crianças têm consciência dos valores sociais que tornam determinado comportamento aceitável ou não. São cientes de que os padrões sociais que constroem uma imagem positiva ou negativa à medida que conseguem atender as expectativas sociais. Além disso, os dados permitiram perceber que, embora elas estejam cientes destes valores, muitas vezes sentem-se impelidas a desobedecê-los por conta da necessidade de pertencer a grupos, mesmo quando estes impõem comportamentos contrários às regras. O problema reside no fato de que a aceitação no grupo também está condicionada a regras internas do grupo. Cada elemento deve fazer as mesmas coisas, mesmo quando contraria os padrões sociais estabelecidos. Isso leva as crianças a hesitarem entre seguir as regras do grupo para serem aceitas pelos amigos e desobedecer as da sociedade, ainda que se sintam culpadas e inadequadas aos olhos desta.

Sou uma menina legal, porque eu converso com as pessoas, eu brinco. Eu sou inteligente e sou educada. Só isso.

Ah, num sei... Eu sou meio rebelde porque eu fico indo na onda das menina. Eu bagunço às vezes, fico rindo da cara de quem cai e, na minha catequese, eu falei com o padre e ele falou pra confessar. E eu confessei que eu fiz bagunça, que eu falei um pouquinho de palavrão, e também que eu e a minha amiga inventamos uma música muito legal. Eu sou boa quando eu obedeço à tia e faço o que as tia pede. E sou má quando vou atrás das menina, bagunço com elas e fico sem ir embora. 
Às vezes sou legal. Quando eu quero fazer alguma coisa, faço as pequenininha ficar rindo e trago alegria. E eu sou chata quando eu não ouço a tia, fico só xingando, falando lálálálálá e só falando palavrão. Mas eu não falo palavrão. Eu não xingo, eu falo só... eu falo assim... "sua feia".

Sou boa. Ah! Eu não sei. Tenho pena das menina pequena. Quando as menina grande quer bater nelas eu não deixo. Elas me chamam de folgada e tudo, mas eu não deixo não, principalmente na minha irmã. Não tão inteligente (Afirma com ênfase e voz alta). Eu não estudo, eu não faço nada, só fico enrolando na sala, eu e a outra. Ah! Eu sou inteligente em matemática e em português. Só isso.

Eu me vejo feliz. Eu vejo uma menina boa, legal, porque eu divido. Quando minha avó traz coisa eu divido com todo mundo.

É, às vezes eu sou chata. Quando alguém pega, dá abraço em mim, beijo, quando fala alguma coisa boa pra mim, eu falo "cai fora daqui, cai". Quando minha irmã vem me dar abraço, beijo, eu bato nela. Quando alguém vai conversar comigo, viro a cara. Também, eu não gosto quando uma menina fica comigo só por que eu tenho coisa. Aí, quando não tenho, ela nem liga, eu odeio, é só por interesse das coisa. Eu sou um pouco, como é o nome que se fala? Muito brava, às vezes, quando alguém mexe comigo eu começo a gritar. E eu sou má, por causa que quando meu pai pedia pra fazer as coisas, eu não fazia, quando eu ia lá pra casa pulava muro, essas coisa. Aí, eu voltava pra casa só à noite. Aí, eu xingava minha mãe, meu pai. Quando nois chegava em casa, meu pai levava nois pra passear de manhã e só voltava à noite. Ai! Quando eu falo essas coisa, me dá vontade de chorar! Antes, quando eu era nova eu era muito boa, obedecia as tia, não entrava nesse barco dessas menina, mas agora... Um dia, quando eu era nova, quando eu cheguei aqui no lar, pulei só um dia o portão da escola. Aí, eu deixei pra trás e só fiquei fazendo coisa boa. Aí, eu comecei ser ruim, a desobedecer as tia. Às vezes, eu xingo elas, aí a tia falou "por que você não é como que era antes?". Às vezes, eu sou boa, eu brinco, eu não arrumo confusão, fico brincando no parquinho ou assistindo minha novela, que é Rebeldes. Eu sou triste. O que me faz triste é quando eu faço coisa ruim pra alguém. Eu não sou inteligente, por causa que eu não faço lição. Eu só fico dormindo lá na sala de aula. A professora fala assim pra mim "eu quero que você melhore por causa que quando você crescer não vai dá pra você arrumar trabalho, você vai ficar catando latinha na rua, quero que você seja uma menina boa, inteligente, eu não quero que você pegue latinha na rua, por causa que quando você crescer você vai ter filho pra criar".

E o que você quer?

Quero ser uma mãe boa, eu quero dar de tudo pro meu filho. E também ensinar coisa boa pra eles, pra quando eles crescer, ele ser bom moço para poder ser um alguém na vida e poder trabalhar, comprar coisa pra dentro de casa. Também, quando eu crescer, eu quero melhorar na escola, aqui no lar e na minha casa, pra quando eu crescer ser uma boa moça, pra mim poder trabalhar, casar, ganhar filho.

Como é eu...hum... Eu não gosto de briga. De vez em quando eu só falo com os outros. Eu não bato, porque a tia disse que dói.

A tia falou pra mim que se os outros me bater é pra eu contar pra ela. Se a tia não tiver na casa, aí eu tenho que falar "não me bate". A tia 
falou pra não deixar me bater. Aí, quando ela chegar, ela faz o relatório. Eu sou um pouquinho boa. De vez em quando eu fico brava, aí eu não mereço... Quando eu fico brava, eu falo pra minha mente "pára de ficar nervosa". Aí, eu paro. Mas, depois, começa de novo.

Não sei... Eu tô mais pra nervosa... Eu sou bonita por dentro... tenho a oportunidade de poder estudar, poder falar. Eu vi que a vida vale a pena. Eu sou boa. Ajudo as pessoas. Ah! Não sou, não sei o que eu sou.

Conte-me sobre essa menina do desenho.

É uma menina que se chama... (diz o próprio nome). Ela é brava, mas ela é legal às vezes, quando consegue compartilhar com as pessoas, quando aprende, quando não faz coisas ruins. E, às vezes, ela é chata, quando mente, quando grita com as pessoas, quando elas pedem as coisas e ela fala não. Ela sempre tem um sim, mas sempre fala não primeiro, pra guardar o sim pra depois. Ela estuda todos os dias, toda semana. Às vezes, ela vai bem na escola, às vezes, ela vai mal de tanta conversa. Às vezes, desobedece à professora.

Eu sou legal, eu não bagunço, obedeço, fico tirando onda com outro. Inteligente, porque eu aprendo. Sou bom porque eu estudo, não bagunço muito, não agrido, nem bato em ninguém, sou feliz e só.

O que te faz feliz?

Tudo, a vida, escola, professora, professor, tias, tios.

O que você quer para sua vida?

Ser rico pra ajudar os pobre, dando comida, dando casa isso. Eu ia ter um monte de gata, ia cuidar do meu filho, jogar fliperama junto com ele, levar ele pro shopping, fazer compras, comprar carro, uma Blazer, uma Mercedes, uma Ferrari, compra moto, compra turbina pro carro, ir pra Nova York e esquecer a gente daqui.

Eu sou assim, quem folga comigo eu folgo também. É assim que funciona. Comigo tem que ter educação tia, se um menino fala que caralho, aí eu faço ele pedir desculpa. Às vezes, sou bom e, às vezes, ruim. Sou bom quando eu não pulo muro, não bato, não mexo com as pessoas e eu sou ruim quando eu bato, subo no muro e brigo. Sou legal porque eu colaboro com as pessoas. Não sou muito inteligente, porque precisa aprender tudo pra ser inteligente. Se aprende tudo, aí que é inteligência. Sou feliz e só.

O que você quer pra sua vida?

Ser veterinário, porque eu gosto de bichos. Aí, minha vida ia ser legal, mais legal do que é hoje, porque eu ia trabalhar. Trabalhar é bom, porque ganha dinheiro pra comprar a minha casa, meu carro. Ficar parado não dá. Quando trabalha esquece.

\section{C) $\underline{\text { Relacionado ao "Senso de Indústria" }}$}

O "Senso de Indústria", Erikson (1971), é imprescindível ao desenvolvimento de um autoconceito e, conseqüentemente, de uma autoimagem positiva para as crianças. Em suas falas, pode-se identificar que elas medem seu valor através de sua capacidade para realizar coisas. Consideram-se boas, legais, inteligentes e felizes quando ajudam os adultos 
Sou boa porque eu ajudo as tias a cuidar das menina. Eu ajudo a tia a arrumar a casa, ajudo a dar lanche pra nois.

Sou mais ou menos inteligente, porque não é todo mundo que sabe de tudo. Mas, sabe por que a gente é inteligente? Porque nós inventa dança, nós dança, canta, nós chora, nós finge quando quer doce, "olha lá o tamanho do mosquito", e pega o doce das menina que fica bobeando.

Num sei... Sou uma menina legal. Sou feliz, uma menina boa, porque faço a lição, aprendo as coisa... sou inteligente, eu estudo. Só.

O que faz de você uma menina legal?

Brincar, ajudar a tia, fazer a lição.

Sou boa. Eu lavo os prato, às vezes eu lavo. Varro a escola, arrumo a cadeira e ajudo a professora. Inteligente, porque eu faço as coisas: escrever, desenhar, pintar.

Sou Inteligente, quando eu faço minha lição todos os dias, quando não falto. Às vezes, eu fico brincando, aí a professora me da bronca, mas ela ta certa, né.

Eu quero crescer pra ficar grand. Aí, eu vou ser o que eu quero, eu vou ser astronauta.

Eu vou trabalhar, ganhar dinheiro pra comprar minhas coisas, ter um carro de verdade, uma casa.

Eu me esforço pra me ajudar. Eu faço as lição, tudo. Depois, eu ajudo a M.. Aí, depois me ajudo sozinha.

Sou feliz.

O que a faz feliz?

Estudar, aprender várias coisas, ensinar o que eu aprendi, saber entender as coisas, brincar com as pessoas, poder ajudá-las. Sempre tem um jeito de ajudar os outro.

Menino de olhos pretos cabelos pretos, deixa eu vê, moreno assim Eu sou mais bom do que ruim, mas também não sou santinho. De bom, eu jogo futebol, eu estudo, eu como muito, eu também vivo ajudando o tio que cuida da horta. Fico sempre na padaria também e, às vezes, de vez em nunca, eu ajudo na cozinha. Acho que só. Noventa e cinco por cento, sou feliz e só cinco por cento, triste. Inteligente, porque estudo muito.

O que você quer ser?

Policial e arquiteto. Prefiro mais astronomia, estudar coisas do espaço. Ser astrônomo é bem melhor. Mas ser uma coisa assim, grande né... astrônomo não é pra qualquer pessoa, tem que estudar muito para ser astronauta.

\section{D) Relacionado ao Bem-Estar}

Quanto ao bem-estar, os relatos das crianças evidenciam que elas desenvolvem um autoconceito positivo ou negativo, dependendo de como se sentem em relação a si e aos outros, do que ocorre ao redor delas e das atividades que realizam. 
Tia, sabia que eu tenho medo de morrer?

Por que? Você acha que vai morrer?

Porque... eu tenho... assim... porque todo mundo morre na vida e eu prefiro morrer primeiro, do que morrer de alguma coisa... Eu prefiro morrer... é assim... é como fala... Ai, esqueci... Quando a gente morre de verdade, sem ser matada... Entende?

Você não quer que ninguém mate você, é isso? Você acha que alguém quer matar você?

Eu penso em suicídio. (Sussurrou)

No que você pensa?

Eu penso assim... se eu for à noite embora, bem a noitão, bem a noitão, aí alguém me mata.

(...)

Você se acha uma menina feliz ou infeliz?

Feliz. Eu sou feliz, dentro de mim. Fora...

Como é dentro de você?

De vez em quando legal, de vez em quando feliz. Ah! Eu acho legal dentro do meu coração, não fora, porque eu sou infeliz fora.

Por que você é infeliz fora?

É chato. Eu fico gritando com todo mundo, porque todo mundo me deixa nervosa, as amigas... as tias...

O que você faz quando fica nervosa?

Eu grito... Eu falo socorro, pareço uma louca. Vem um negócio aqui (aponta para o próprio peito), o vento bate aqui, bate forte aqui, oh.

Sou cinqüenta por cento chato e cinqüenta por cento legal. Eu sou legal quando eu tô jogando futebol, quando tô em visita, quando é final de semana, quando eu tô estudando astronomia e geografia. Eu sou chato quando é aula de português, aula de história, quando eu tenho que ir pra aula de dança quando tem campeonato aqui e eu to jogando, e a professora me tira pra colocar outro. Aí, eu fico tocando na banda. Aqui tem uma banda e eu não gosto porque eu podia ta lá brincando, jogando futebol lá fora. Quando a gente chega da escola só sai na hora da janta, depois da janta a gente vai lá pra casa. De vez em nunca, a gente fica aqui fora como hoje. Aí, eu fico com vontade de brigar, mas eu não faço, mas fica chato pra mim. 
Recapitulando os relatos das crianças sobre sua auto-imagem, foi possível avaliar que, embora elas não a tenham relacionado diretamente à sua trajetória de vida, elas têm noção de que seus antecedentes definem quem são, mas encontram dificuldade em verbalizar essa consciência. Em compensação, as crianças foram capazes de associar a visão do amigo, a imagem corporal e o autoconceito à visão que tem de si.

A criança em idade escolar, via de regra, é consciente de sua condição social e de que esta influencia a forma como é vista e valorizada pela sociedade. Por essa razão, a posição sócio-econômica exerce efeitos significativos sobre sua auto-imagem.

Isso ocorre "quando o escolar começa a sentir que a cor de sua pele, os antecedentes de seus pais, a qualidade de suas roupas decidirão, mais que seu desejo e sua vontade de aprender, de seu valor como aprendiz e, assim, de seu sentimento de identidade". Erikson (1971)

"Numa sociedade altamente competitiva, é inevitável que a autoestima decorra em parte da percepção que o indivíduo tem de sua posição e de seu prestígio em grupos relevantes. Na medida em que os símbolos e as realidades do status sócio-econômico, do fato de pertencer a um grupo minoritário e outros indicadores da estrutura social trazem implicações de status, espera-se que eles afetem o desenvolvimento da autoconsideração e da identidade". Hess (1978)

A depreciação da auto-imagem também está relacionada aos vínculos familiares. No que toca à ausência de uma figura materna protetora, a perda da mãe por morte ou a sua falta por negligência ou violência (abuso psicológico, físico ou sexual), influenciam a auto-imagem da criança e sua auto-estima.

Nos casos em que as crianças perderam suas mães, nem o pai, nem os demais famíliares assumiram o cuidado delas, razão pela qual foram encaminhadas ao abrigo. Em decorrência, as crianças perderam também suas casas e o contato com pessoas significativas. De um momento para outro, tudo o que Ihes era familiar, desaparece. Essa perda de referências 
interfere em sua auto-imagem uma vez que a mãe, a casa, os amigos, etc, constituem um conjunto de elementos que definem a identidade da criança.

Em sua casa, a criança é filha de alguém, moradora em um bairro residencial, amiga de um vizinho próximo, etc. Em um abrigo, a criança perde esses papeis sociais. Por exemplo, na casa ela é filha; na escola, ela é aluna. E no abrigo, o que ela é? No abrigo, a criança deixa de ter um papel social, o que a torna socialmente invisível, sem imagem própria.

Além disso, quando a mãe morre e o pai se omite ou não pode assumir o cuidado da criança, esta é levada a romper importantes vínculos afetivos. O comportamento de apego é um forte sentimento gerado pela dependência da criança à figura materna. Essa dependência é um momento do desenvolvimento infantil necessária para aquisição da auto-confiança.

"Nenhuma forma de comportamento é acompanhada por sentimento mais forte do que o comportamento de apego. As figuras para as quais ele é dirigido são amadas, e a chegada delas é saudada com alegria. Enquanto uma criança está na presença incontestada de uma figura principal de apego, ou a tem ao seu alcance, sente-se segura e tranqüila. Uma ameaça de perda gera ansiedade, e uma perda real tristeza profunda; ambas as situações podem, além disso, despertar cólera”. Bowlby (1990)

Além da dor e da raiva geradas pela perda da figura de apego, quando não estão aptas para lidar com sentimentos tão intensos e conflitantes, as crianças perdem uma importante referência para um desenvolvimento psicossocial saudável. São os cuidados maternos e as relações afetivas satisfatórias com adultos significativos que propiciam o desenvolvimento da confiança, da autonomia e da iniciativa, elementos indispensáveis para a construção de uma auto-imagem positiva.

Nos casos das crianças vítimas de violência, embora as mães estivessem vivas, as relações afetivas não eram satisfatórias, pois eram permeadas por negligência ou maus-tratos. Suas necessidades, tanto físicas quanto emocionais, não foram supridas. Estes fatores levam as crianças a um sentimento de frustração e inadequação. 
Um sentimento de inferioridade pode emergir devido ao fato das figuras de apego funcionarem como espelhos. "Vários fatores combinados fazem da mãe e do pai um espelho extremamente importante na vida de seu filho: a prolongada dependência dos pais para satisfação física e emocional, o permanente contato com eles, e o fato de que os reflexos de si mesmo, vistos através dos pais, constituem as suas primeiras experiências". Para a criança, os pais são tão importantes quanto Deus. Briggs (1986)

A criança entende que "esses deuses todo-poderosos" a tratam como merece ser tratada. $O$ que eles dizem a seu respeito é o que ela acredita ser. Usando a comunicação verbal e não-verbal dos pais para construir sua auto-imagem, a criança luta para se enquadrar na visão que tem de si mesma. É uma imagem a qual busca corresponder. Briggs (1986)

A criança vítima de violência sente-se humilhada e desvalorizada, pois acredita que o seu comportamento desencadeou a agressão. Elas internalizam a culpa.

"Para se considerar uma pessoa realmente adequada e sentir-se bem interiormente, a criança precisa de experiências de vida que the provem que tem valor e que é digna de ser amada. Não basta dizer à criança que ela é especial. A experiência é que importa. Ela fala mais alto do que as palavras". ${ }^{3}$ Briggs (1986)

As experiências de vida satisfatórias são importantes para 0 desenvolvimento das relações de respeito e de confiança entre os pais e a criança. A principal causa de uma personalidade instável e angustiada é a dúvida quanto à aceitação de si pelas figuras de apego. Há "fortes razões para se acreditar que o alicerce sobre o qual se constrói uma personalidade estável e autoconfiante é a certeza descuidada de contar com a presença e o apoio das figuras de apego". Bowlby (1993)

Os sentimentos de confiança ou desconfiança na figura de apego desenvolvem-se, gradativamente, durante a infância e permanecem mais ou menos inalterados por toda a vida. Esses sentimentos são reflexos das

\footnotetext{
${ }^{3}$ Grifos do autor
} 
experiências afetivas de cada pessoa. Uma vez, desenvolvido um vínculo de confiança com figuras de apego, a criança se sente mais feliz e confiante para explorar novos territórios e tentar novas experiências. Bowlby (1993)

"Uma bem fundada autoconfiança (...) não apenas é compatível com a capacidade de confiar em outros, mas brota dessa capacidade e é dela complementar. Além disso, ambas são produto de uma família que dá a seus filhos forte apoio, que thes respeita as aspirações pessoais, o senso de responsabilidade e a capacidade de lidar com o mundo. Dessa forma, longe de comprometer a autoconfiança de uma criança, muito a estimulam a base segura e o forte apoio proporcionados pela família". Bowlby (1993)

Portanto, a confiança em uma figura de apego é imprescindível para o desenvolvimento da autoconfiança da criança e, conseqüentemente, para a construção de uma auto-imagem positiva.

Contudo, é obvio que os pais não são os únicos espelhos das crianças, outras pessoas também funcionam como tal no decorrer do desenvolvimento da criança. Todas as pessoas que mantenham contato constante com elas - avós, tios, irmãos, vizinhos, professores, babás e os amigos - influenciam a construção de sua auto-imagem, sendo que, durante a fase escolar, os amigos são fundamentais nesse processo. Briggs (1986)

"Mais ou menos aos seis anos, a criança se liberta da dependência total da família. A maneira pela qual outras crianças, que não as de sua casa, reagem a ela torna-se cada vez mais importante. Ela verifica logo que os outros valorizam certas qualidades. E o fato de possuir ou não essa qualidade afeta a idéia que faz de si mesma. Os meninos tendem a valorizar a capacidade atlética, a força física e a coragem. As meninas, em geral, notam mais os atrativos físicos, a boa aparência, a sociabilidade e a cordialidade. Dão a ternura e às virtudes morais maior prioridade do que os meninos". Briggs (1986)

"As crianças que têm suas características valorizadas pelas outras crianças da mesma idade sentem-se mais adequadas do que aquelas que não dispõem desses atributos, porque recebem repetidos reflexos positivos 
do grupo. As crianças cujos interesses e valores discordam visivelmente das outras de sua idade provavelmente se sentirão isoladas - e verão a si mesmas como pessoas de menor valor. A partir dos seis anos, e com maior intensidade à medida que se aproxima da adolescência, toda criança necessita do apoio social das demais cujos valores correspondem aos seus". Briggs (1986)

Isso ficou evidente nos relatos das crianças sobre sua imagem corporal. As que tinham características físicas desvalorizadas pelos amigos sentiam-se inadequadas e insatisfeitas com seu corpo e sua aparência.

A imagem corporal exerce forte influência sobre o autoconceito, sobretudo aos escolares e adolescentes. Ela faz referência à percepção dos atributos físicos (grande, pequena, gorda, magra, etc.), das características psicológicas (capacidades e habilidades corporais) e das sociais (comparação do seu corpo com o do outro). whaley \& wong (1999)

"O índice de crescimento, o nível de energia, a capacidade física, a aparência, a força, a inteligência, a cordialidade, a habilidade e as deficiências de uma criança, provocam reações nos outros. A criança chega a conclusões sobre quem é, em parte, baseada nas suas próprias observações de si mesma, em comparação com os outros, e, em parte, na reação desses outros para com ela. E cada reação aumenta ou diminui os seus sentimentos de valor próprio". Briggs (1986)

As atitudes dos outros em relação às capacidades da criança são fundamentais para ela. A existência de uma deficiência não é tão importante quanto as reações das pessoas que a cercam. As atitudes de pena e desprezo fazem com que a criança se sinta defeituosa. A imagem que tem de si torna-se negativa dependendo da relação com o outro. Briggs (1986)

Os resultados mostram que a visão do outro não exerce influência apenas na imagem corporal das crianças, mas também no seu autoconceito. Brincar, ter amigos, corresponder às expectativas sociais, realizar tarefas em conjunto, ou seja, todas relações que demandam o convívio com o outro, são importantes na construção da auto-imagem das crianças. Para elas, o 
principal agente socializador são os jogos e as brincadeiras, pois através deles formam seus grupos e estabelecem sua rede de amizade.

Manter contatos sociais e pertencer a grupos são ações que refletem na auto-imagem das crianças. Esses vínculos geram uma avaliação positiva da criança em relação a seus pares. A aceitação dos amigos está relacionada à sua auto-estima. As falas das crianças demonstraram que 0 simples fato de terem amigos influencia positivamente seu autoconceito.

"A brincadeira fornece uma organização para a iniciação de relações emocionais e assim propicia o desenvolvimento de contatos sociais". Winnicott (1971)

Através das brincadeiras, as crianças aprendem sobre si e o outro, sobre normas de conduta social e aprendem a controlar impulsos e a lidar com frustrações.

"Os jogos e as brincadeiras são uma saída para a expressão e elaboração de sentimentos, sendo meios de lidar com conflitos e com o imprevisto, com vivências desagradáveis e ameaçadoras". Mead apud Sant'Ana; Resende; Ramos (2004)

Embora, perceba-se facilmente que as crianças brincam por prazer, dificilmente as pessoas reconhecem que as crianças brincam para dominar impulsos e idéias que, se não forem controlados, levarão à angústia. Winnicott (1971)

"A brincadeira e o jogo constituem uma forma de interação social imprescindível à formação humana, por permitir a expressão infantil se realizar mais plenamente sem o temor das conseqüências das ações ali ocorridas. A interação social na brincadeira permite à criança construir as suas próprias referências socioculturais ao se colocar no lugar do outro na tentativa de incorporá-lo". Mead apud Sant'Ana; Resende; Ramos (2004)

A interação social permite às crianças assumir papéis alternados, o que Ihes dá um conhecimento real sobre o mundo sócio-moral, incluindo seu sistema de papéis e regras da ordem social. Kohlberg apud Hoffman (1978) 
O desenvolvimento da moral segundo Kohlberg possui seis estádios ordenados em três níveis de orientação moral: nível pré-moral, nível da moralidade de conformação com o papel convencional e nível da moralidade de princípios morais aceitos para si mesmo. Kohlberg apud Hoffman (1978)

A criança em idade escolar encontra-se no nível da moralidade de conformação com o papel convencional. No inicio dessa fase, desenvolve a "moralidade do bom menino", que consiste em manter boas relações. A criança se orienta para agradar e auxiliar outras pessoas. Ao julgar os outros, considera as intenções e tem a concepção de uma pessoa moralmente boa. No final da fase, desenvolve a "moralidade da autoridade e da manutenção da ordem social". Orienta-se para "o cumprimento do dever" e para demonstrar respeito pela autoridade, mantendo uma determinada ordem social. Adota a perspectiva de outras pessoas que têm direitos e expectativas legítimas na situação. Kohlberg apud Hoffman (1978)

Ao analisar os relatos das crianças sobre seu autoconceito fica evidente que elas tem noção de valores morais como: solidariedade, compaixão, obediência e das atitudes e comportamentos esperados delas, e que se avaliam como boas ou más, à medida que conseguem corresponder a estas expectativas.

O que torna esta uma questão complexa é o fato do comportamento das crianças estar intimamente relacionado à sua auto-imagem, portanto, quanto pior o comportamento de uma criança, pior é sua auto-imagem. Em conseqüência do mau comportamento, a criança é repreendida e punida; e dependendo da maneira como isso ocorre, reafirma a opinião negativa que ela tem sobre si.

A criança percebe também que a sociedade espera que ela seja produtiva e, como deseja ser valorizada, busca aprovação auxiliando os adultos na realização de tarefas. Ela desenvolve o "senso de indústria", isto é, torna-se uma unidade viva e integrada de uma situação produtiva. Completar uma atividade produtiva passa a constituir um objetivo para conquistar a consideração do outro. Erikson (1971) 
À medida que a criança cumpre tarefas, é elogiada e recompensada, - que leva a um sentimento de adequação e, conseqüentemente, ao fortalecimento de sua auto-imagem, principalmente se isso ocorrer em áreas que lhe são importantes.

Realizar coisas que the dão prazer aumenta sua auto-estima. Em contrapartida, realizar tarefas que não gosta faz com que se sinta frustrada. Muitas vezes, expressa essa insatisfação de maneira agressiva, mas, como tem consciência de que a agressividade não é socialmente aceitável, sente culpa e se auto-avalia de forma negativa.

Um bom meio ambiente deve ser capaz de tolerar os sentimentos agressivos, se estes fossem expressos de forma mais ou menos aceitável. Winnicott (1971)

"A imagem que toda criança tem de si mesma é produto dos numerosos reflexos que fluem de muitas fontes: o tratamento que recebe das pessoas à sua volta, o domínio físico sobre si mesma e sobre o ambiente, e o grau de realização e reconhecimento em áreas que são importantes para ela. Esses reflexos são como instantâneos de si mesma que ela cola num álbum imaginário de retratos, e que formam a base de sua identidade. Tornam-se a sua auto-imagem ou autoconceito - suas respostas pessoais à pergunta "Quem sou eu?"' Briggs (1986) 


\section{CONSIDERAÇÕES FINAIS}

O presente trabalho teve o propósito de apreender o significado da experiência de abrigo à criança nessa condição social e identificar nos relatos das crianças referências a respeito de sua auto-imagem.

Com relação ao significado da experiência de abrigo, pode-se apreender que as crianças o simbolizam como um lugar de formação, orientação e educação, que supre algumas de suas necessidades, mas que não consegue suprir suas necessidades afetivas, principalmente, no que diz respeito à figura materna.

O princípio da institucionalização consiste em retirar a criança de uma situação de risco para propiciar seu desenvolvimento, é uma medida de proteção. No entanto, os relatos das crianças mostram que a separação da família causa sofrimentos que interferem no desenvolvimento de sua autoestima.

Com relação à auto-imagem, pode-se identificar nos relatos que a trajetória de vida, as interações sociais e a capacidade de realização influenciam a auto-imagem da criança.

Desse modo, conclui-se que a experiência de abrigo interfere na construção da auto-imagem das crianças, uma vez que todas as experiências vividas influenciam sua auto-imagem. Interfere de forma positiva, ao retirar as crianças de ambientes hostis e agressivos que lesavam seu desenvolvimento, e de forma negativa, ao privar a criança do contato familiar.

Os dados permitem mostrar que a auto-imagem também interfere no significado da experiência de abrigo, uma vez que, a maneira como nos vemos interfere no modo como nos comportamos e nos relacionamos com o meio.

Quanto mais positiva a auto-imagem de um indivíduo, melhor ele se relaciona com o mundo. Ao internalizar conceitos negativos sobre si, as crianças agem utilizando os mecanismos psíquicos que dispõem, 
idealizando as relações familiares, apresentando comportamentos agressivos e delinqüentes.

O abrigo deve ser uma medida, considerada entre as várias possibilidades de encaminhamento, como uma alternativa para salvaguardar a integridade física e psíquica da criança e do adolescente em situação de risco social e pessoal. O abrigamento deve ser uma possibilidade e um direito para todas as crianças que dele necessitarem, independentemente, de sua classe social. Fromer (2002)

É necessário cuidar para não se admitir crianças nas instituições por pertencerem a famílias pobres. Elas já sofrem o ônus da desigualdade e injustiça social e não podem ser lesadas também em seu direito a convivência familiar.

Muitas famílias colocam seus filhos em entidades de abrigo quando estão desempregos ou sem casa para morar. Essas famílias recorrem ao abrigo como uma única saída para essas situações. Não se trata de abandono, mas de uma estratégia de sobrevivência. Somente 10\% dos abrigados são realmente órfãos. A maioria tem familiares que não têm condições de atender as necessidades básicas de seus filhos em dado momento. Boletta, Magri, Vicente, et al (1997)

Para essas famílias, é necessário buscar alternativas que assegurem o convívio familiar e comunitário, tais como: inserção em programas de assistência social; aumento de vagas em creches e pré-escolas; e programas de apoio sócio-educacional.

As crianças não podem ser penalizadas passando sua infância e adolescência em abrigos, privadas da convivência familiar por incompetência das autoridades responsáveis. Existem alternativas para as crianças em situação de risco, que precisam ser retiradas de seus lares devido a sua situação de extrema vulnerabilidade. A colocação de crianças em famílias substitutas e a agilidade nos processos de adoção são medidas viáveis. $O$ ECA determina que os abrigos têm a incumbência de colocar a criança em família substituta, quando esgotados os esforços em mantê-la na família de 
origem (Art 92), e de manter a autoridade judiciária informada sobre os casos em que o reatamento dos vínculos familiares é inviável (Art 94, inciso VI). Brasil (1990)

Cabe aos abrigos, identificar essas situações e comunicar as autoridades judiciárias. Isso deve ser realizado com seriedade e rapidez, pois quanto maior for o tempo de institucionalização, menor são as chances de adoção ou colocação em família substituta.

Essas são algumas alternativas para se assegurar um direito primordial da criança e do adolescente: O Direito à Convivência Familiar. 


\section{Referências Bibliográficas}

Alvarez AM, Leite de Moraes MC, Rabinovich EP. Resiliência: um estudo com brasileiros institucionalizados. Rev Bras Cres Desenv Hum, 1998; 8(1/2): 70-75.

Boletta A, Magri C, Vicente CM et al. Dez medidas básicas para a infância brasileira. São Paulo: Fundação Abrinq; 1997.

Bowlby J. Apego. São Paulo: Martins Fontes; 1990.

Bowlby J. Separação. São Paulo: Martins Fontes; 1993.

Briggs DC. Criança feliz: o desenvolvimento da autoconfiança. São Paulo: Martins Fontes; 1986.

Carvalho MdoCBde. Coordenador. Estatuto da Criança e do Adolescente: Trabalhando Abrigos. São Paulo: Instituto De Estudos Especiais Da Puc/ Centro Brasileiro Para a Infância e Adolescência; 1993. (Cadernos de ação $3)$.

Constituição Federal - 1988.

Delgado TB, Ribeiro MO. Levantamento sobre os serviços de saúde às crianças carentes nos abrigos da cidade de São Paulo. Revista da Sociedade Brasileira de Enfermeiros Pediatras, 2002; 2(1): 21-28.

Duarte JC, Arboleda MR. Malos tratos y abuso sexual infantil. Madri: Siglo Veinteuno de Spaña; 1997.

Erikson Eh. Oito idades do homem. In: infância e sociedade. $2^{\underline{a}}$ ed. Rio de Janeiro: Zahar; 1971.

Estatuto da Criança e do Adolescente - Lei Federal № 8069, 13/07/90.

Fromer L. $\mathrm{O}$ abrigo: uma interface no atendimento à criança e ao adolescente vítimas de violência intrafamiliar. In: Ferrari DCA, Vecina TCC, organizadoras. O fim do silêncio na violência familiar: teoria e prática. São Paulo: Ágora; 2002. p. 311-315. 
Hess RD. Desenvolvimento moral. In: Carmichael: Manual de psicologia da criança. São Paulo: EPU; 1978. 9 p. 335-477.

Hoffman ML. Desenvolvimento moral. In: Carmichael: Manual de psicologia da criança. São Paulo: EPU; 1978. 9 p. 1-159.

http://portal.prefeitura.sp.gov.br/cidadania/conselhosecoordenadorias/cmdca/ legislacao/0014. Acessado (31/05/06).

Http://Pucsp.Br/Publique/Cgi/Cgilua.Exe/Sys/Star.Htm?Infoid=455\&Sid=172. Acessado (21/03/2005).

Jorge MHPM. Crianças, adolescentes e jovens no Brasil no fim do século. In: Westphal MF, organizadora. Violência e criança. São Paulo: Edusp; 2002. p. 47-70

Lane STM. O que é psicologia social. São Paulo: Editora Brasiliense; 1983.

Mahon KA, Fowler MD. Moral development and clinical decision-making. Nurs Clin North Am 1979; 14(1): 3-12.

Maldonado MT. Caminos de la prevención de la violencia domestica y escolar: construyendo la paz. Adolesc. Latinoam, 1998; 1(2): 111-117.

Marcilio ML. A roda dos expostos e a criança abandonada na história do Brasil. 1726-1950. In: Freitas MC, organizador. História social da infância no Brasil. 3ª ed. São Paulo: Cortez Editora; 2001. p. 53-79.

Martins CS. A compreensão de família sob a ótica de pais e filhos envolvidos na violência doméstica contra crianças e adolescentes [dissertação]. São Paulo: Escola de Enfermagem de Ribeirão Preto da Universidade de São Paulo; 2005.

Mccown DE. Moral development in children. Pediat. Nurs 1984; 10(1): 42-44.

Minayo MCdeS. O desafio do conhecimento: pesquisa qualitativa em saúde. 8e ed. São Paulo: Hucitec; 2004. 
Mussen Ph. Et Al. Desenvolvimento na média meninice. In: Desenvolvimento e personalidade da criança. $4^{a}$ ed. São Paulo: Harbra; 1977. p. 351-402.

Nogueira PC, Costa LF. A criança, a mãe social e o abrigo: limites e possibilidades. Rev Bras Cres Desenv Hum, 2005; 15(3): 36-48.

Piaget J. El juicio y el razonamiento en el niño: estudio sobre la logica del niño. Buenos Aires: Guadalupe; 1972.

Rabinovich EP. A casa como símbolo: a relação mãe-criança. Rev Bras Cres Desenv Hum, 1997; 7(1): 34-48.

Ribeiro MO. A criança de/na rua em idade escolar: um olhar sobre sua trajetória de vida [tese]. São Paulo: Escola de Enfermagem da Universidade de São Paulo; 1999.

Sant'Ana RB, Resende CA, Ramos LC. O interacionismo social e a investigação da brincadeira infantil: uma análise teórico-metodológica. Rev Bras Cres Desenv Hum, 2004; 14(3): 11-26.

Scliar M, Um país chamado Infância. Porto Alegre: Sulina; 1989.

Sousa e Silva MA. Violência contra crianças: quebrando o pacto do silêncio. In: Ferrari DCA, Vecina TCC, organizadoras. O fim do silêncio na violência familiar: teoria e prática. São Paulo: Ágora; 2002. p. 73-80.

VecinaTCC, Cais ACFS. Infância e adolescência: uma realidade que precisa de intervenção. In: Ferrari DCA, Vecina TCC, organizadoras. O fim do silêncio na violência familiar: teoria e prática. São Paulo: Ágora; 2002. p. 5770.

Winnicot DW. A criança e o seu mundo. Rio de Janeiro: Zahar editores; 1971.

Winnicot DW. Privação e delinqüência. São Paulo: Martins Fontes; 1999.

Wong DL. Whaley \& Wong enfermagem pediátrica: elementos essenciais à intervenção efetiva. $5^{\mathrm{a}}$ ed. Rio De Janeiro: Guanabara Koogan; 1999. 


\section{Anexo 1}

São Paulo, de 2005.

Prezado (a) Senhor (a).

Sou aluna da Escola de Enfermagem da USP e, no momento, estou desenvolvendo um projeto de pesquisa que compreenderá a dissertação de mestrado do curso de pós-graduação da referida Escola. Para dar continuidade à pesquisa preciso entrevistar crianças em situação de abrigo com idade entre seis e doze anos. Por essa razão, venho a V. Sa. Solicitar autorização para realizar entrevistas no abrigo que está sob sua responsabilidade.

O estudo busca apreender o significado da experiência de viver em abrigo e identificar a auto-imagem das crianças nessa condição através da análise de seus discursos.

O intuito deste trabalho é permitir que a criança em situação de abrigo tenha a oportunidade de expressar sua realidade e assim sensibilizar os profissionais de saúde para a atenção à criança em situação de abrigo oferecendo material acadêmico que possibilite a discussão e a visualização da inserção destes profissionais neste campo de atuação.

Certa de contar com a sua colaboração, desde já agradeço sua atenção.

Respeitosamente,

Daniela Cristina Montes 


\section{Anexo 2}

Oi, nome da criança!

Meu nome é Daniela.

Estou aqui para fazer um trabalho de minha escola.

O trabalho é para conhecer as crianças que moram em abrigos como este. Por isso, venho aqui para conversar com as crianças. Eu chamo essa conversa de entrevista. Durante a entrevista, peço para a criança desenhar ela mesma e o lugar onde mora. Depois, peço a ela para contar uma estória sobre seu desenho.

A entrevista precisa ser gravada. Se você quiser participar, você poderá ouvir sua história no final da entrevista. Só você! Ninguém, além de você e eu, saberá que foi você quem me contou.

Se você tiver alguma dúvida, fique à vontade para me perguntar o que quiser.

Você quer fazer a entrevista? Mesmo que decida participar, você poderá desistir a qualquer momento. E, se você não quiser participar, tudo bem.

Antes de começarmos eu vou ler para você o que está escrito neste papel. É um "Termo de Consentimento" que, depois de eu terminar de ler, você precisará assiná-lo, caso concorde com o que está escrito nele. 


\section{Anexo 3}

\section{Termo Consentimento}

$\mathrm{Eu}$,

de

anos,

declaro que concordo em participar da entrevista conduzida pela Daniela Cristina Montes.

Sei que a entrevista está sendo realizada para conhecer melhor as crianças que vivem em abrigos.

Farei um desenho e contarei uma história sobre meu desenho, em segredo à Daniela. Sei que a entrevista será gravada, mas ninguém, além dela, saberá o meu nome, somente o que eu contar. Ninguém está me obrigando a isso e sei que, se eu quiser, posso deixar de falar a qualquer momento. E, se eu tiver alguma dúvida sobre o assunto, poderei perguntar a ela.

O que eu disser será transformado em um trabalho que será apresentado em sua escola, para ajudar as pessoa a conhecer melhor a criança que vive no abrigo.

São Paulo, de de2005.

Criança:

Responsável:

Pesquisadora:

Daniela Cristina Montes

Fone: 3242-2244

Comitê de Ética em Pesquisa da EEUSP Escola de Enfermagem da USP

Av. Dr. Eneas de Carvalho Aguiar, 419.

Cerqueira César - CEP: 05403-000

Fone: 3066-7548 